Regulatory and Institutional Issues Impeding Cleanup at U.S. Department of Energy Sites:

Perspectives Gained from an Office of Environmental Restoration Workshop
W. E. Fallon
R. D. Quinn
J. M. Gephart
L. A. Stevenson
R. E. Gephart

May 1991

Prepared for the

U.S. Department of Energy

Office of Environmental Restoration

and Waste Management

under Contract DE-AC06-76RLO 1830

Pacific Northwest Laboratory

Operated for the U.S. Department of Energy

by Battelle Memorial Institute 


\title{
DISCLAIMER
}

This report was prepared as an account of work sponsored by an agency of the United States Government. Neither the United States Government nor any agency thereof, nor Battelle Mernorial institute, nor any of their employees, makes any warranty, expressed or implied, or assumes any legal liability or responsibility for the accuracy, completeness, or usefuiness of any information, apparatus, product, or process disclosed, or represents that its use would not infringe privately owned rights. Reíerence herein to any specific commercial product, process, or service by trade name, trademark, manufacturer, or otherwise does not necessarily constitute or imply its endorsement, recommendation, or favoring by the United States Government or any agency thereof, or Battelle Memorial institute. The views and opinions of authors expressed hercin do not nccessarily state or reflect those of the United States Government or any agency thereof.

\author{
PACIFIC NORTHWEST LABORATORY \\ operated by \\ BATTELLE MEMORIAL INSTITUTE \\ for the \\ UNITED STATES DEPARTMENT OF ENERGY \\ under Contract DE-ACO6-76RLO 1830
}

Prinled in the United States of America

Available to DOE and DOE contractors from the

Office of Scientific and Technical Iníturmation, P.O. Box 62, Oak Ridge, TN 37831; prices availatle from (615) 576-44U1. FIS 626-8401.

Available to the puhlic from the National Technical Iniormation Service,

U.S. Department of Commerce, 5285 Port Royal Rd., Springfield, VA 22161. 


\section{REGULATORY AND INSTITUTIONAL ISSUES IMPEDING CLEANUP AT U.S. DEPARTMENT OF ENERGY SITES: PERSPECTIVES GAINED FROM AN OFFICE OF ENVIRONMENTAL RESTORATION WORKSHOP}
W. E. Fallon
J. M. Gephart
R. E. Gephart
R. D. Quinn
L. A. Stevenson

May 1991

Prepared for
the U.S. Department of Energy
Office of Environmenta 1
Restoration and Waste Management
under Contract DE-AC06-76RLO 1830

Pacific Northwest Laboratory

Richland, Washington 99352 
. 


\section{PREFACE}

The U.S. Department of Energy's (DOE) nuclear weapons and energy operations are conducted across a nation-wide industrial complex engaged in a variety of manufacturing, processing, testing, and research and development activities. The overali mission of DOE's Office of Environmental Restoration and Waste Management (EM) is to protect workers, the public, and the environment from waste materials generated by past, current, and future DOE activities and to bring the DOE complex into compliance with all applicable laws, regulations, and agreements related to health, safety, and the environment. EM addresses this broad mandate through related and interdependent programs that include corrective actions, waste operations, environmental restoration, and technology development.

EM activities and programs are subject to more than two dozen federal statutes. Principal among these are the Resource Conservation and Recovery Act, the Comprehensive Environmental Response, Compensation and Liability Act, the Atomic Energy Act, and the National Environmental Policy Act. Other regulatory requirements are set forth in state and local statutes, DOE Orders, standards, and other guidance documents.

In addition to regulations, EM programs are frequently affected by operational or oversight responsibilities exercised by other DOE organizations. Principal among these are the major statutory program areas of the Offices of Defense Programs, Energy Research, and Nuclear Energy; the Office of Environment, Safety and Health (EH); the Office of the Controller; the Office of the General Counsel; and the Office of Civilian Radioactive Waste Management.

Given this degree of programmatic scope, statutory constraint, and organizational interface, EM faces an increasingly complex array of regulatory and institutional issues. The EM office of Environmental Restoration (EM-40) recognizes the importance of implementing a complex-wide process to identify and resolve those issues that may impede progress towards site cleanup. As a first step in this process, EM-40 sponsored an exercise to identify and 
characterize major regulatory and institutional issues and to formulate integrated action steps towards their resolution. The exercise also complemented and supported EH policy activities.

This report is the first product of that exercise. It is intended that the exercise described here will mark the beginning of an ongoing process of issue identification, tracking, and resolution that will benefit cleanup activities across the DOE complex. Although participation in this exercise was limited to DOE and Management and Operations contractor staff, it is intended that the results reported here will serve as a basis for subsequent activities that will include broader representation. It is envisioned that the action items described and the individuals who developed them could serve as a point of departure for further developing ideas and dialogue in collaboration with regulatory agencies, states, regions, tribes, and other concerned parties and organizations.

The approach described here has been used previously by Pacific Northwest Laboratory for similar objectives. The success and limitations of the approach may offer valuable lessons for planning future workshops. To this end, appendixes are included that document operational details of the exercise. 
SUMMARY

The Pacific Northwest Laboratory conducted an exercise sponsored by the U.S. Department of Energy's (DOE) Office of Environmental Restoration to identify and suggest solutions for high-priority regulatory and institutional issues that are impeding site cleanup activities. The exercise was conducted in two steps. The first step was a series of conference calls and meetings with selected DOE Field Office and Headquarters (HQ) staff and Management and Operations (M\&O) contractors. These were designed to capture the universe of issues of concern, to cite specific examples, and to indicate how individual sites and offices are currently coping with the issues confronting them. These conversations and discussions were transcribed and distilled into an issue summary document that clustered the issues into 13 issue groups:

- Regulatory Integration

- Regulatory Streamlining

- Cleanup Authority and Consistency

- Environmental Management Integration

- Implementation of Agreements/Documentation

- U.S. Environmental Protection Agency Issues

- General DOE Guidance and Administration

- Risk Management

- Future Land Use

- Cleanup Levels

- DOE Infrastructure

- Information Systems

- Community Relations Programs.

The second step was a workshop for 43 participants held on December 17 and 18, 1990, in Gaithersburg, Maryland. After reviewing and refining the 
13 issue groups, participants selected five for detailed discussion in working groups. These were:

- Regulatory Streamlining/Integration

- Genera1 DOE Guidance and Administration

- Cleanup Levels/Cleanup Authority and Consistency

- Environmental Management Integration

- Implementation of Agreements/Documentation.

The working groups reviewed, prioritized, characterized, and expanded on issues included under each of these five issue groups with the goal of developing sequential action items that could be implemented in the field or at HQ.

Workshop participation met the objective of a balanced representation of $\mathrm{HQ}$ and Field office staff. Of 43 attendees, 25 were from the field and 18 were from HQ. Headquarters representation included 11 from the office of Environmental Restoration, six from the office of Environment, Safety and Health, and one from the Office of General counsel. Field representation included ten from DOE, nine M\&O contractors, and six National Laboratory personnel. 


\section{CONTENTS}

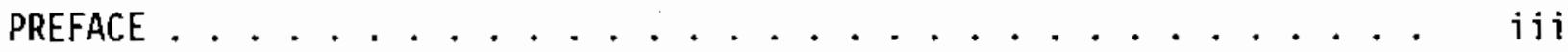

SUMMARY .....................

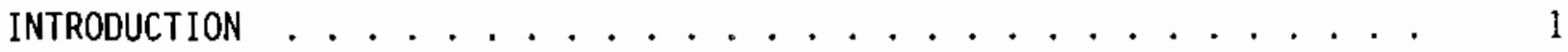

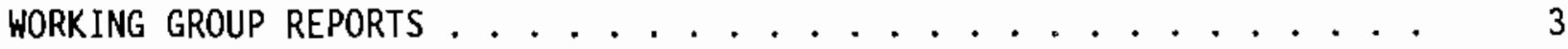

ISSUE GROUP - REGULATORY STREAMLINING . . . . . . . . . . . 5

GROUP MEMBERSHIP ....................... 5

ISSUE PRIORITY AND SELECTION . . . . . . . . . . . 5

ISSUE 1 : EXTENT OF CHARACTERIZATION ........... 6

Discussion ....................... 6

Suggested Action Items ............. . . 7

ISSUE 2: DOCUMENT REVIEW AND APPROVAL TIME . . . . . . . . 8

Discussion .................... 8

Suggested Action Items . . . . . . . . . . . 8

ISSUE 3: TECHNOLOGY BASELINE . . . . . . . . . . . 10

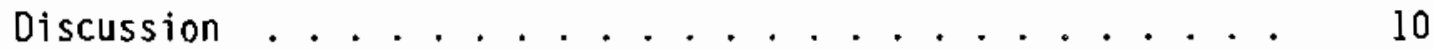

Suggested Action Items ............. . . 10

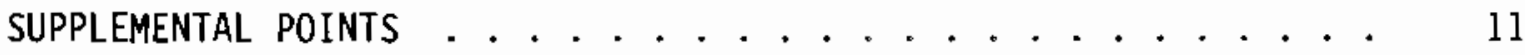

NPL Versus Non-NPL Sites .............. 11

Limited or Expedited Cleanups ............ . 12

NEPA/CERCLA Integration .................. 13

RCRA/CERCLA Functional Equivalency . . . . . . . . 13

ISSUE GROUP - GENERAL DOE GUIDANCE AND ADMINISTRATION . . . . . . 15

GROUP MEMBERSHIP .......................... 15

ISSUE PRIORITY AND SELECTION . . . . . . . . . . . . 15 
ISSUE 1: DELEGATION OF AUTHORITY AND RESPONSIBILITY . . . . . 15

Discussion ....................... 15

Suggested Action Items . . . . . . . . . . . 17

ISSUE 2: ADMINISTRATIVE REQUESTS .................... 18

Discussion ....................... 18

Suggested Action Items ............. 19

ISSUE GROUP - CLEANUP LEVELS/CLEANUP AUTHORITY AND CONSISTENCY . . . . 21

GROUP MEMBERSHIP ........................ 21

ISSUE PRIORITY AND SELECTION . . . . . . . . . . . 21

Issue Group - Cleanup Levels . . . . . . . . . . 21

Issue Group - Cleanup Authority and Consistency . . . . . . 21

ISSUE 1: THERE IS NO PROCESS TO ESTABLISH CLEANUP LEVELS

FOR DOE SITES .......................... 22

Discussion ....................... 22

Suggested Action Items . . . . . . . . . . . 23

Supplemental Points............... . . . . 24

ISSUE GROUP - ENVIRONMENTAL MANAGEMENT INTEGRATION . . . . . . . 27

GROUP MEMBERSHIP . . . . . . . . . . . . . . . . 27

ISSUE PRIORITY AND SELECTION . . . . . . . . . . . . 27

ISSUE 1: TSD OF WASTE GENERATED FROM ER ACTIVITIES . . . . . 28

Discussion . . . . . . . . . . . . . . . 28

Suggested Action Items . . . . . . . . . . 30

ISSUE 2: WASTE MINIMIZATION ................ 30

Discussion .................... 30

Suggested Action Items ............. 31

Supplemental Points. . . . . . . . . . . . . 32 


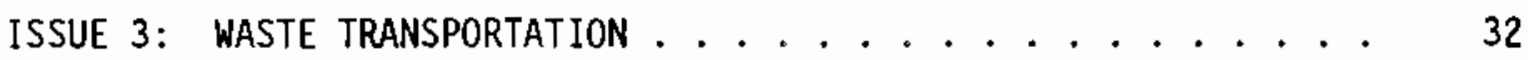

ISSUE GROUP - IMPLEMENTATION OF AGREEMENTS/DOCUMENTATION . . . . . 33

GROUP MEMBERSHIP ........................ 33

ISSUE PRIORITY AND SELECTION . . . . . . . . . . . . 33

ISSUE 1 : PEIS/FUTURE LAND USE .................. 33

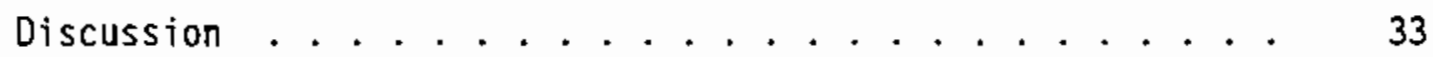

Suggested Action Items . . . . . . . . . . 35

ISSUE 2: IMPLEMENTATION OF FFAs/IAGS ........... 36

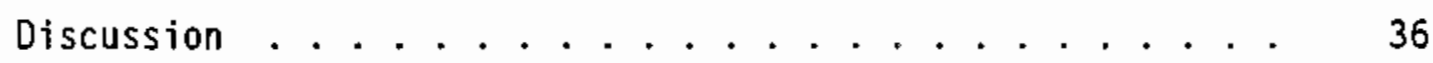

Suggested Action Items . . . . . . . . . . . . . 37

Supplemental Points . . . . . . . . . . . . 38

ISSUE 3: INTERAGENCY RELATIONS . . . . . . . . . . . 38

Discussion ................. . . 38

Suggested Action Items ............. . . 38

CONCLUSIONS AND RECOMMENDATIONS . . . . . . . . . . . . . 41

LIST OF ACRONYMS AND INITIALISMS . . . . . . . . . . . . . 43

APPENDIX A - PRELIMINARY ISSUE IDENTIFICATION AND CHARACTERIZATION . . A.I

APPENDIX B - REGULATORY AND INSTITUTIONAL ISSUES WORKSHOP . . . . . B. B.I

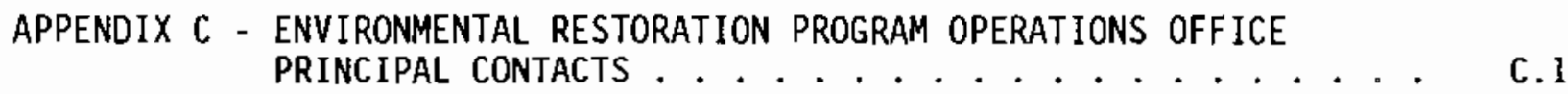

APPENDIX D - CONFERENCE CALL/INTERVIEW INFORMATION . . . . . D.

APPENDIX E - LIST OF ISSUE GROUPS, SUPPORTING INFORMATION, AND $\ldots \ldots$. . . . . . . . . . . . .

APPENDIX $F$ - WORKSHOP INFORMATION PACKET ........... F.I

APPENDIX G - GENERAL WORKSHOP INFORMATION .............. G. . . .

APPENDIX H - POTENTIAL RESOURCES FOR ADDRESSING WORKSHOP

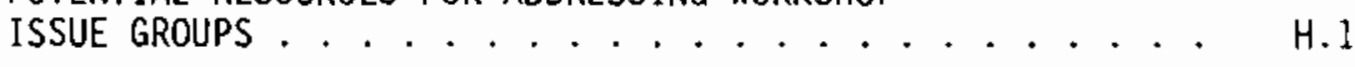


.

. 


\section{INTRODUCTION}

The array of issues, problems, and constraints confronting the U.S. Department of Energy (DOE) as it begins environmental restoration activities is extensive and complex. The list of considerations includes, but is by no means limited to budget, policy, law, regulations, administration, public affairs, science, engineering, health, welfare, and national security. The task of making progress despite this range of impediments is a daunting one. Recognizing the difficulty of resolving or even addressing all these issues concurrently, DOE's Office of Environmental Restoration (EM-40) initiated a process to begin addressing two of its most difficult categories of issues: 1) those deriving from regulations, and 2) those from DOE's institutional structure and operating procedures. Pacific Northwest Laboratory (PNL) staff planned and implemented this process for EM-40.

Regulatory and institutional issues often overlap. Moreover, both of these categories also overlap other kinds of issues. However, in general terms, the following definitions apply:

- regulatory issue - an impediment to progress arising from overlapping, conflicting, unclear, flawed, or missing regulatory statutes, directives, or guidance

- institutional issue - an impediment to progress arising from a lack of or a weakness in 1) DOE's internal communication linkages or operational interfaces; 2) the definition of roles, responsibilities, and authorities within and between DOE Headquarters (HQ), Field Offices, National Laboratories, support contractors and regulators; and 3) policy and policy implementation guidance.

The decision to focus on these two categories reflects EM-40's belief that the resolution of other issue categories will be expedited and facilitated if regulatory and institutional problems are addressed and resolved early in DOE's site cleanup effort. The decision to solicit extensive input on a broad array of issues from Field Office and HQ staff involved in environmental restoration activities via conference calls, interviews, and a highly participative workshop reflects the belief that the resolution of complex-wide problems will require the integration of perspectives and experiences from both $\mathrm{HQ}$ and the Field offices. 
The following sections are the reports presented by working groups at the workshop he1d December 17 and 18, 1990, in Gaithersburg, Maryland. Conclusions and recommendations from the PNL team are also given. Extensive use is made of appendixes that describe details of the planning and execution of the conference calls, HQ meetings, and the workshop as a reference for potential use or adaptation in future exercises. Appendix A describes the process for identifying and characterizing issues, which was primarily through conference calls to the Field offices and interviews with HQ staff from EM-40 and the Office of Environment, Safety and Health (EH). Appendix B describes the format and execution of the December regulatory and institutional issues workshop. Appendixes $\mathrm{C}$ through $\mathrm{H}$ include $\mathrm{lists}$ of participants in all parts of the exercise; the entire list of issues; materials given out before, during, and after the workshop; and a resource 1 ist for addressing the workshop issue group. 


\section{WORKING GROUP REPORTS}

The following sections contain the working group reports presented to the plenary session on the second day of the workshop. Both before and during the workshop, participants were encouraged to exercise flexibility relative to the suggested discussion format. Given this latitude, it is not surprising that the different groups exercised different prerogatives, such as restating the problem that the issue group addressed, integrating the various issues into a single issue for discussion purposes, differentiating the issues into component subissues, or commenting on related topics.

In documenting the group reports, every effort has been made to balance the advantages of a consistent format with the obligations to faithfully convey each group's thought processes, products, and prerogatives. Likewise, every effort was made to incorporate reviewers' comments that were not otherwise addressed and that further developed the workshop discussions. The following format was judged to provide the best balance and was used for each of the five working group reports.

- group membership - identification of the members and affiliations of the small group as well as the group leader and facilitator

- issue priority and selection - a review of the issues included in the original issue group and subsequent additions, deletions, and modifications; identification of the issues selected for discussion.

For each issue the group discussed, the report then presents

- discussion - an elaboration of the issue. Depending on the direction that the group discussion took, this section may focus on general characteristics of the issue, historical factors, sitespecific examples, current regulatory or institutional considerations, or the subissues that comprise the issue.

- suggested action items - a delineation of specific actions that could be implemented by the Field Offices or HO to ameliorate or resolve the issue or its component subissues. The items identified during the workshop have been sequentially ordered to the extent possible.

- supplemental points - peripheral or related points or summary observations. 
. 


\section{ISSUE GROUP - REGULATORY STREAMLINING}

\section{GROUP MEMBERSHIP}

Susan Brechbi11, D0E-San Francisco (Group Leader)

Roy Gephart (Facilitator), Pacific Northwest Laboratory

Lyle Harris, DOE-HQ, EM-44

Fred Hoffman, Lawrence Livermore Nationa] Laboratory

Randy Kaltrejder, DOE-HQ, EH-22

Autar Rampertaap, DOE-HQ, EM-45

Bill White, DOE-Argonne

Andre Williams, DOE-HQ, EM-55

\section{ISSUE PRIORITY AND SELECTION}

The group reviewed the following six issues contained in the original issue group, Regulatory Streamlining:

- Permitting Process

- Document Review and Approval Times

- Extent of Site Characterization

- Technology Baseline

- Limited or Expedited Cleanups

- National Priorities List (NPL) Versus Non-NPL Sites.

In addition, the working group addressed the three issues found under another issue group, Regulatory Integration:

- Resource Conservation and Recovery Act (RCRA)/Comprehensive Environmental Response, Compensation and Liability Act (CERCLA) Functiona] Equivalency

- National Environmental Protection Act (NEPA)/CERCLA Integration

- Other Regulatory Integration Concerns.

From these nine issues, three were chosen for discussion:

1. Extent of Site Characterization

2. Document Review and Approval Times

3. Technology Baseline. 


\section{ISSUE 1: EXTENT OF CHARACTERIZATION}

\section{Discussion}

The crux of this issue is the need for all interested parties (DOE, the regulatory community, and.stakeholders) to agree on how much site characterization data are needed before cleanup work begins. There is a general impression that everyone wants more data so as to reduce the risk associated with decision-making. This often results in generation of excessive data; that is, data that do not actually reduce risk certainty. The group believed that the extent of characterization should be closely tied to site-specific collection requirements. Neither less data nor more data is necessarily better in all cases. One must factor in site-specific data, such as cleanup levels, cleanup technology selection, land use, local regulatory preferences, environmental heterogeneity (or homogeneity), and quality/quantity of the existing data base.

Participants noted that technicaliy defensible work plans should begin with solidly established data quality objectives (DQOS) and should include built-in flexibility that enables DOE to negotiate or renegotiate characterization levels. DOE should continue to limit the degree of detail found in the agreements, per se. Specifics such as the number of characterization wells to be drilled in the future should be included in revisable work plans or scope statements that are appended to the agreements. The point is to avoid predetermined "strategies" that do not permit past characterization findings to guide future characterization work. DOE should also strongly consider interim measures, especially if they achieve Applicable or Relevant and Appropriate Requirements (ARARs) for a site.

$E H$ and $E M$ are currently engaged in a joint effort to streamline the entire Remedial Investigation (RI)/Feasibility Study (FS) process, with special attention on the nature and extent of site characterization. To date, these efforts have centered on the evaluation, presentation, and potential application of the observational approach to environmental restoration efforts at severa $700 E$ sites. Recently, EH and EM have sponsored efforts to integrate 
the observational approach with the U.S. Environmental Protection Agency's (EPA) DQO methodology in an attempt to provide greater refinement to the site characterization process.

Close coordination with regulatory agencies through frequent technical meetings is essential for large-scale RI/FS activities.

Suggested Action Items

The following action items were recommended:

- Publish guidance to assist sites in integrating and implementing the DQO approach and the observational approach. Apply the integrated approach at one or more sites as a test case of the approach's practicality and applicability.

- Analyze the cleanup process carefully to identify those actions and decision points for which schedule, cost, and regulatory compliance may be significantly impacted by characterization activities.

- Develop an approach to the cleanup process in which data acquisition is an integral part of the planning. This approach should emphasize feedback of data needs from anticipated critical analyses essential to decision making, such as risk assessment and examination of alternate remedies. The level of certainty required for those decisions should be estimated a priori and used to drive the DQOS for the characterization activities. The approach should include an analysis of the degree of risk associated with alternative cleanup strategies and how characterization may or may not reduce risk.

- Collect, collate, and interpret existing environmental data. Have results peer-reviewed. Take a systenatic approach that sequentially defines data needs, examines existing data to meet those needs, and then implements a characterization program to collect the missing data required to proceed expeditiously with cleanup work.

- Limit data collection during RIs to that needed to select a remedy. Supplement data needs to fine-tune remedies during the Record of Decision (ROD) process and remedial actions.

- Define and continually re-define DQOS. These should factor in such information as the sources and extent of contamination, transport mechanisms and pathways, and risk and cleanup needs.

- Negotiate/renegotiate scopes of work of agreenents to reflect the DQO approach rather than a predetermined/prescriptive characterization approach. 
The following items were suggested by reviewers:

- Involve regulators at the conceptual stages of a cleanup project to potentially expedite the later review process. If they are involved from the beginning in data collection, determining cleanup levels, selecting a cleanup technology, and determining future land use, reviews would require less time and changes because the regulators would be reviewing a cleanup strategy that they understood from its conception.

- Use an "observational approach," i.e., plan for uncertainties with built-in contingencies.

\section{ISSUE 2: DOCUMENT REVIEW AND APPROVAL TIME}

\section{Discussion}

While both external and internal document review problems were acknow?edged, emphasis was placed on internal review because DOE has direct control of it at this time.

In relation to internal document reviews, the group noted that there is no defined process for $\mathrm{HQ}$ review or tracking of documents. The Field offices have no single point of contact, the submittal process itself is undefined, and review times are based on "applying pressure." Generally, reviews for simple materials such as Categorical Exciusions (CXs) for field characterization activities are taking months. There is concern that as the number and complexity of documents increase, DOE will become even less able to handle the work load. HQ's reluctance to delegate review authority down the 1 ine, either within HQ itself or to the Field offices complicates this issue. For example, the Office of Environmental Restoration and Waste Management (EM-1) does not appear sensitive to the dates on which documents are due to the regulators in enforceable cleanup agreements.

\section{Suqgested Action Items}

The following action items were recommended:

- Establish DOE-HQ review procedures that must be followed. (There was some discussion that EM-40 may have a]ready started this activity.) 
- Convey to Field Offices up front any concerns HQ has regarding these documents so that the concerns can be addressed as documents are written. Also, documents should be considered approved if $\mathrm{HQ}$ comments are not received on schedule.

- Examine the programmatic impact (time and dollars) of HQ review times on all documentation associated with Federal Facility Agreements (FFAs).

- Negotiate or renegotiate realistic schedules in the Interagency Agreements (IAGs)/FFAs/Consent Agreements to take into account needed review times both at the Field Office and $\mathrm{HQ}$ levels.

- Develop and implement a document tracking system to assure reviews are completed on schedule.

- Systemize document review to draw on site-wide risk/review anaiysis. Create, review, and disseminate document macros and templates to Field offices, so that only deviations would need HQ approval/ review. Expand on EM-40's existing FFA tracking program.

- Develop criteria for the type of documents submitted to HQ. The criteria should limit $\mathrm{HQ}$ review to key, high-level reports. $\mathrm{HQ}$ could also do random reviews as a quality assurance check.

- EH has developed the Graphical Approach to Guidance packages to guide people in complying with complex requirements. Similar packages should be developed to guide people through the review process in standard document formats.

- Establish normal timeframes for HQ review of different types of documents. This would allow the Field Offices to factor into document release schedules a review time tailored to the nature of the document.

- Define the primary purpose of HQ review (e.g., to identify "show stoppers" or to build in national consistency) and incorporate in the guidance.

- Schedule $H Q$ and Field office technical reviews to occur concurrently.

- Use standardized document formats (e.g., to first-order headings) to facilitate review process. While the detajls and suborder headings would match Field office needs, some high-level standardization would assure HQ that certain key topics would be addressed in various reports. 
The following items were recommended by reviewers:

- Regulators should not be involved in concurrent technical reviews with HQ and Field offices.

- DOE should arrange meetings with the states to explain funding mechanisms for allowing additional state personnel or contractors to review documents.

- There is a need to examine the programmatic impact (time and dollars) of HQ review times on all documentation associated with FFAs.

\section{ISSUE 3: TECHNOLOGY BASELINE}

\section{Discussion}

The group approached the issue of a technology baseline from the perspective of DOE needing to define what cleanup problems could be addressed today versus those requiring technology development. The gap between existing and needed technologies would help define work to be undertaken by the office of Technology Development (EM-50). In other words, the technology gap should determine where EM places its technology development budget. As the existing technology base is extended by the introduction of new technologies, this information must be effectively and widely disseminated.

The capabilities of some currently used and available commercial technologies are not well communicated across DOE. Communication is fragmented, making technology needs hard to define. Technology development is a multiyear process, especially when starting with basic research and development (R\&D). Future needs must be anticipated long before the technology is applied.

The potential availability of expert-type systems, such as the Remedial Action Assessment System (RAAS), which include technology information components, should be better communicated to the field. In reviewing this group report, however, one reviewer noted that $E H$ has sponsored a complex-wide presentation of a 4-day course on environmental regulations targeted at midlevel managers. RAAS was presented during the discussion and was well received. Also, an article on RAAS appeared recently in the RCRA/CERCLA Update, a newsletter published by EH with a circulation of more than 500 within DOE. 
Suggested Action Items

The following action items were recommended, both within the workshop and by reviewers after the workshop:

- Define DOE complex-wide cleanup requirements.

- Assess cleanup capabilities of present technology as applied to DOE needs.

- Establish a central clearinghouse for access, storage, and release of quality-assessed cleanup technology information. Keep the system maintained and updated.

- Issue a periodic (e.g., quarterly) technical newsletter to keep the Field offices apprised of key developments. This newsletter could also serve as a source of information to industry of DOE technology needs.

- More effectively explain the role of EM-50 to the DOE complex.

- Appoint an EM-50 liaison to each Field office to ensure communication of key developments.

- Define projected technology development needs for both the Field offices and $\mathrm{HQ}$.

- Hold technical seminars with cross-cutting federal, state, and industrial participation.

- Develop a program similar to the EPA's Superfund Innovative Technology Evaluation (SITE) program and make use of lessons learned to improve any similar DOE effort.

- Disseminate information on a private sector participation program being developed by $E M$ to enhance $D 0 E^{\prime} s$ access to commercial technologies.

- Submit an annual technical report from field offices to HQ that delineates technical assessments and performance.

- Integrate and distribute an annual report from all sites to all Field offices.

- Provide guidance at HQ level on providing a budget for non-NPL sites. 


\section{SUPPLEMENTAL POINTS}

The following supplemental information was discussed by the group.

\section{NPL Versus Non-NPL Sites}

It was thought that EH had already established guidance on how non-NPL sites were treated in the DOE and regulatory areas. Generally, the requirements for each are the same though it was recognized that NPL sites received priority funding and emphasis by regulators.

Current policy in DOE Order 5400.4 states that "DOE will enter into IAGs and/or FFAs at both NPL and non-NPL sites, as appropriate... for the execution of RI/FSs and remedial actions under the requirements prescribed in DOE 5400.2A and under Section 120(e) of CERCLA." Where response is carried out under another authority (e.g., RCRA corrective action), DOE must "ensure that these corrective actions are not inconsistent with the NCP in order for them to satisfy CERCLA requirements." The Tiger Teams have interpreted this language to mean that cleanups at non-NPL sites may be taken under another authority, but that such cleanups must al so meet all CERCLA requirements. EH-22 and EH-23 have disagreed with this interpretation, but the Tiger Team maintains their right to this interpretation until such time as the Order is changed. In addition, EH-231 is currently in the process of revising DOE Order 5400.4. The current draft revision states that if a non-NPL cleanup is being taken under a non-CERCLA authority (e.g., RCRA corrective action, state $1 \mathrm{aw}$ ) and includes public participation requirements, such cleanup need not be supplemented to meet CERCLA requirements. Non-NPL sites that do not come under any other cleanup authority should be conducted in accordance with CERCLA requirements (removal or remedial, as appropriate). However, it is important to note that this draft has not yet been reviewed by all appropriate HQ offices, so it may not reflect the final policy.

With regard to regulatory policy, National Contingency Plan preamble language at 55 FR 8698 (March 8, 1990) states that at NPL or non-NPL sites, EPA has discretion to use its authorities under CERCLA, RCRA, or both to achieve cleanup. 


\section{Limited or Expedited Cleanups}

The group asked if DOE was using interim actions (remedial or removal) actions enough or at a11. If yes, is this information being communicated (publicized) to the nearby communities? Such communication would show cleanup progress and "bias for action." DOE needs to develop policy and guidance on this issue and advise the field offices when and how removal actions can be performed. On the other side, the question was raised whether DOE is misusing the removal authority in some cases.

\section{NEPA/CERCLA Integration}

The group believed this issue was already receiving high-level attention within DOE, the Department of Justice, and the Council on Environmental Quality (CEQ), and therefore further discussion in the workshop was not warranted. Ray Berube of $\mathrm{EH}$ presented an excellent overview of this issue during his introductory remarks. It was felt that integration continues to be an issue because "people don't like what they are hearing."

RCRA/CERCLA Functional Equivalency

The group thought this should not be an issue because either CERCLA or RCRA should prevail. The regulators should agree with some given documentation that would satisfy both RCRA and CERCLA. Federal Facility Compliance Agreements are key to up-front concurrence from regulators. However, some participants did not agree that the issue is that simple. For example, at Hanford, the state won't agree to any cleanup standards less than background, despite the fact that EPA under CERCLA would allow health-based standards. Data and procedures may reach equivalency, but actual work is a problem.

Additionally, EPA distributed a July 11, 1990, policy memorandum concerning the applicability of RCRA corrective action authority at NPL sites. EH recently contacted EPA's Office of Federal Facilities regarding application of this policy to federal facilities environmental restoration sites. EPA stated that it is pursuing this policy with federal facilities. However, EPA cautioned that this policy is subject to change depending on the outcome of the Rocky Mountain Arsenal lawsuit, which centers on whether CERCLA supersedes RCRA authority at NPL sites. 
In summary, the group believed that the Regulatory Streamlining issue group ultimately reflected the lack of both adequate guidance and funds. Consequently, effective communication is lacking. Uncertain issues are given a lower priority, and a backlog develops. Better guidance and procedures will help DOE to work more effectively with the regulators, resulting in a more streamlined regulatory process. 


\section{ISSUE GROUP - GENERAL DOE GUIDANCE AND ADMINISTRATION}

GROUP MEMBERSHIP

Joe Cullen, DOE Livermore Site Office

Paul Davis, Sandia National Laboratories

Keener Earle, West inghouse Idaho Nuclear

Ray Greenberg, DOE-HQ, EM-45

Steve Mellington, DOE-Nevada

Rich Sena, DoE-Albuquerque (Group Leader)

Bob Sleeman, DoE-Oak Ridge

Lisa Stevenson (Facilitator), Battelle Human Affairs Research Center

\section{ISSUE PRIORITY AND SELECTION}

The group reviewed the eight issues within the issue group:

- Delegation of Authority and Responsibility

- Administrative Requests

- Budget and Funding

- Cleanup Subcontractors

- Liability Protection for Staff and Contractors

- Use of Existing Environmental Data

- Quality Assurance/Quality Control Standards

- Protracted Procurement cycle.

The group then prioritized the issues and chose the following two as most important to address during the workshop:

1. Delegation of Authority and Responsibility

2. Administrative Requests.

\section{ISSUE 1: DELEGATION OF AUTHORITY AND RESPONSIBILITY}

Discussion

The group first proposed a fundamental restatement of this issue: DOE is not working as a team or using its resources as well as possible. Ideally, 
DOE should work as a team, "passing the ba11" back and forth from EM, as well as its other offices, to other organizational components, with problems and actions in one area leading to involvement of other components as appropriate. However, in contrast to this ideal teamwork mode1, micromanagement, lack of concrete policy guidance, and overly centralized decision-making are prevalent in EM. The Japanese model of team building and empowerment should be the operative philosophy.

The group felt this restated issue included the following subissues:

- HQ role - HQ should focus more on policy development and less on micromanagement. Many problems arise from EM's micromanagement. EM keeps authority, but delegates responsibility. They should be delegated concomitantly. In addition, there is a lack of resolution of policy issues. EM should negotiate national policies before sending directives to the Field offices, otherwise the Field offices are put in the middle between EM and the regulators. A key function of EM is to work closely with EH in addressing and ultimately resolving regulatory issues. The Director must take the lead in resolving issues with the EPA, states, and other agencies. This practice is particularly important given the degree of autonomy states and EPA Regions have. To accommodate this autonomy, it is important that decision-making responsibilities for dealing with states and EPA regions reside at the Field office level. A HQ/Field office team should clarify who should review what, how value is added, and what is the policy.

- partnership - There is a need to define roles and encourage a spirit of partnership between $\mathrm{HQ}$ and the Field Offices. Empowerment at the lowest level is needed. Private industry is increasingly receptive to this idea, but it is inconsistent with the centralized authority of EM-1. There is a need to define more clearly and explicitly roles and responsibilities and push decision-making authority down to lower levels. However, reluctance to delegate and a lack of confidence are normal in a new organization. Implementing management plans should be a top priority.

- oversight versus EM-40 1ine management - An overemphasis on oversight is taking resources away from 1 ine management, even though the Secretary has stated that line management is key to EM's success. Care should be taken to ensure that line management is provided with adequate resources.

- lack of process for technical review. 


\section{Suggested Action Items}

The most fundamental action is to define clearly the functions, responsibi]ities, and linkages that should be in effect. These should be defined in the $\mathrm{HQ}$ and Field office management plans. The group recommended the following actions and roles to assist in developing consistent and coordinated management policies for EM activities:

EM-1 Recommended Role:

- Define policy.

- Solve policy problems.

- With EH support, resolve policy issues with regulators before sending guidance to Field offices.

- Request funding adequate to meet regulatory requirements rather than refusing field office estimates because the regulatory requirements are viewed unfavorably.

- Provide resources to the field.

EM Staff Recommended Role:

- Develop policy.

- Track Field Office implementation of policy.

- Get EM-1 focused on major actions.

- Be EM lead in resolving issues with EH, GC, or Field Offices.

Field Office/M\&O Contractor Recommended Roles:

- Implement policy.

- Bring policy issues to EM staff attention.

- EM-1's management plan and charter are under development. Parallel documents for EM-30, EM-40, and EM-50 are al so being developed. The group recommends Field office involvement in the development, not just the review of these documents. The management plans should be developed in accordance with partnership principles.

- Ensure that the EM program management plans define

- operational philosophy

- decision authorities and delegation

- HQ/Field office roles and responsibilities. 
To begin resolving key regulatory and technical issues, the following sequence of actions should be taken.

1. Form a HQ/Field office group to further define key policy issues.

2. HQ and Field Offices develop jointly an action plan that consolidates, prioritizes, and focuses various site-specific action plans. EH-5, $E H-20, E M-30, E M-40$, and EM-50 should be represented on the task force for developing the plan.

3. HQ issues implementing orders to the Field Offices.

4. Identify performance indicators for EM. The Office of Nuclear Energy (NE) has been given the lead to develop DOE-wide performance indicators. A similar effort for EM could be coordinated with NE.

The following additional comments were made by reviewers:

- Develop a process for the Field offices and HQ to reach conscientious decisions and forward-moving paths when "pushbacks" occur with the regulators.

- Hold Field Offices reviews at HQ twice yearly to give an opportunity to discuss lessons learned.

- Establish a procedure whereby a Field office can successfully demonstrate the ability to handle particular activities and thus have authority delegated for those activities.

\section{ISSUE 2: ADMINISTRATIVE REQUESTS}

\section{Discussion}

The group believes that administrative requests are often characterized by redundancy and a lack of coordination, and that the Tiger Teams have frequently compounded the problem.

Field offices recognize that HQ often must respond to various needs outside of its control, such as requests from the Secretary or the Office of Management and Budget. In such cases, quick-turnaround requests are understandable. However, other requests to the Field offices could be better planned and scrutinized by HQ to make sure the information isn't already at HQ. Administrative requests are a resource drain and very expensive for the 
Field offices to respond to. Too many requests are poorly coordinated, redundant, and reflect a lack of EM and EH coordination and communication.

Also, Tiger Team assessments have shifted the emphasis previously placed on ER activities and redirected it to lower priority needs that now get too much funding and attention. A Tiger Team often misses major compliance issues and recommends actions that are inconsistent with EM policies and priorities. These recommendations need to be reviewed or checked for validity and sensitivity before being transmitted as action items back to the Field offices. A key issue is the validity of findings. How many reviews are needed to ensure that a job is being done properly? Lack of trust appears to be an underlying issue, especially with M\&O contractors.

One reviewer closely involved with the Tiger Team program commented that the group discussion reflected a faulty perception of Tiger Team function and procedures. The following points were noted.

- The Tiger Teams do not make recommendations, establish priorities or determine funding levels. These activities are the responsibility of the Program Offices (and, through the program office, the DOE line organization and Management and Operations (M\&0) contractor).

- The Tiger Team process has been designed to ensure that both verbal and written information have been verified by all the participants in the assessment process (M\&O contractor, DOE line organization, DOE Program 0ffices, and regulators). Team meetings are open to all participants, and written materials are subjected to multiple reviews for factual accuracy by participants.

- The Tiger Team assessments have been comprehensive. The reports have received much public and congressional scrutiny. A11 draft and final assessment reports are placed in DOE public reading rooms.

- EM is currently required to provide concurrence on the action plans developed in response to each assessment before the Secretary's approval of the plan for implementation.

- EM is routinely asked to provide representatives to participate in the Tiger Team process and provide recommendations with regard to the scope of each individual assessment.

\section{Suggested Action Items}

- Screen HQ requests before passing to Field offices. All requests should go through an EM-40 advocate for screening before passing on 
to the Field 0ffice. The purpose is to prioritize, eliminate unnecessary requests and avoid or at least minimize "fire drills." The EM advocate would determine if data are already at $\mathrm{HQ}$, determine the benefit versus cost of the request, and at tempt to provide time for a quality response. A centralized data base is under development within EM-43 that will provide a resource for this activity.

- Inform Field Offices why information is needed. HQ requestors need to explain the reason for requests and changes. Currentiy, these reasons are not always obvious. The Field offices would take the requests more seriously if they understood why the information is needed and how it will be used. It would also help the Field offices better tailor the information.

The following items were suggested by reviewers:

- Establish HQ protocol for administrative requests including approval hierarchy and a formal electronic tracking system. Direct computer linkage to Field offices would facilitate requests for data, which could then be formatted by HQ to fit its needs.

- Establish single contact points (staff and organization) for administrative requests.

- Develop an information tracking system to capture the results of administrative requests.

- Determine if the information has already been provided to another HQ office. Minimize the use of contractors in seeking information directly from the Field offices.

- Establish an EM-Field Office coordination group, perhaps by region.

- Forecast HQ requests twice yearly to the Field Offices to minimize resource-intensive fire drills.

- Evaluate the need to include EM in the major System Acquisition Program, and if included, to what degree.

- Use the Waste Information Network so that data are at hand and can be easily retrieved. 


\section{GROUP MEMBERSHIP}

Dave Brown, Allied Signal, Inc.

Tom Buqo, Earth Techinology, Las Vegas

George Dixon, DOE-HQ, EM-20

Bob Faron, DOE-HQ, GC-11

Lisa Feldt, DDE-HQ, EH-221

Julie Gephart (Facilitator), Pacific Northwest Laboratory

Roger Landon, Westinghouse Hanford Company

Janice Longstreth (Facilitator), Pacific Northwest Laboratory

Dave Swindle, Martin Marietta, Oak Ridge (Group Leader)

\section{ISSUE PRIORITY AND SELECTION}

Two issue groups, which originally had a total of eight issues, were addressed by this working group.

Issue Group - Cleanup Levels

- Limited Cleanup Standards

- Basis for Cleanup Levels

- Flexibility of Remedial Action Cleanups

- Common Terminology Requirements.

Issue Group - Cleanup Authority and Consistency

- Cleanup of Sites Not Under DOE's Control

- State Versus Federal Authority

- Requirements for DOE Versus Private Industry

- Consistency Among EPA Regions and States.

Instead of prioritizing and focusing on these eight issues individually, the group decided to address them collectively. The eight issues were integrated into a single issue: There is no process to establish cleanup levels for DOE sites. 
ISSUE 1: THERE IS NO PROCESS TO ESTABLISH CLEANUP LEVELS FOR DOE SITES

Discussion

For the past 20 years, various environmental statutes have been enacted with little or no integrated or consistent guidance on how they should be implemented across all media. Consequently, many federal and state cleanup efforts have proceeded without the benefit and guidance of specified action limits, such as the ARARs. The situation is exacerbated by the fact that when ARARs do exist, they are often in conflict relative to the precise level of cleanup that is required.

Cleanup parameters are primarily based on regulations rather than on available technology or risk. These regulations often tend to be extremely conservative. Because the regulators have control over DOE site cleanup, DOE has perceived itself to be subject to the edict "comply or die," no matter how stringent or unrealistic cleanup levels are. In addition, there is inconsistent cleanup terminology used among sites, lack of specifically defined cleanup levels, and little or no consideration by the regulators of the dif ferences among the various DOE sites.

In regard to cleanup levels, DOE is in a unique position. DOE has its applicable orders and procurement restraints to contend with and must also deal with ten highly autonomous EPA regions and numerous states and municipalities, all of which have their own inconsistencies in defining cleanup standards. All these factors argue for a site-by-site approach to cleanup levels, which makes it difficult for DOE to implement a consistent approach to its complex-wide cleanup mission.

Funding is limited, and without a process or system in place to establish cleanup levels based on site-specific needs and parameters, as opposed to strict regulatory guidance, DOE can't effectively achieve maximum risk reduction benefits for the dollars spent.

Because of the wide range of cleanup problems at the DOE sites, a single, national DOE standard for cleanup levels is not reasonable. Instead, what is needed is development of a methodology for a process to estabiish appropriate cleanup standards on a site-by-site basis. National standards 
won't be applicable to all sites; therefore, site-specific flexibility is needed. A process that provides consistent, systematic guidance among DOE sites would provide sites with a framework to follow, while also providing the flexibility to apply them to a particular site's different needs.

It may be impossible to establish cleanup levels that all regions and states agree to. However, guidelines could be established with a rationale to be used when negotiating cleanup levels. This practice would hopefully keep levels for similar sites close to each other.

Suggested Action Items

The group suggested several steps towards development of flexible cleanup standards at DOE sites.

- EH-20, in conjunction with EM, has established a DOE working group for risk-based standards. One objective of the working group will be to develop a risk-based approach for such standards that can be applied across the DOE complex and possibly to other non-DOE sites (e.g., the U.S. Department of Defense (DOD) or private sector). This group should be the focal point for all DOE activities relating to the development of risk-based standards, and will report on the status of the group's activities to all DOE elements on a regular basis. This group should be the point of contact and coordination with EPA's risk-based approach.

- Develop a white paper on flexible cleanup standards that factors in technology, risk, and site-specific parameters and the various concerns of competing regulators. The paper should include a rationale for cleanup and an action plan for developing a consistent approach or methodology for cleanup standards and levels.

- In regard to long-term storage and disposal of wastes, establish a de minimis level for storage, and in turn, an upper limit or boundary of cleanup below which a site can be stabilized with little or no monitoring. Technical limitations, health risks, prior work, and site-specific factors must all be considered.

- Develop a guidance document at HQ describing the methodology for cleanup standards development. The document should emphasize the need for flexibility and that standards (ARARs) must be developed on a site-by-site basis. The document should also encourage development of ARARs early in the RI/FS process.

- After developing proposed standards (ARARs), begin negotiations with regulators. ARARs can be updated, modified, and improved at 
any time during the RI/FS process. This is an iterative process to be performed concurrently with characterization studies.

- Identify/evaluate existing methods for setting cleanup levels. This evaluation should include methods used for radionuclides and hazardous chemicals. Examples where standards are in place include the Formerly Utilized Sites Remedial Action Program (FUSRAP) at 0ak Ridge, the Uranium Mill Tailings Reclamation Action Program (UMTRAP), as well as EPA, DOD, and the U.S. Nuclear Regulatory Commission (NRC). Those standards and methods need to be reviewed and evaluated for "lessons learned" from which DOE can benefit.

- Catalog the current situation at DOE sites, recognizing the different scenarios at each site. Such a catalog would include waste types, releases, and site characterization as well as types of facjlities (Decontamination and Decommissioning, operations, waste management) and RCRA/CERCLA requirements to determine the "universe" DOE must deal with. In addition, analyze prior experience at sites such as Weldon Spring that have completed several stages that must proceed the remedial action.

- Ask the National Academy of Sciences to form a panel to review the advantages and disadvantages of flexible risk-based cleanup standards.

- Establish acceptable levels of risk or a procedure for establishing risk. The acceptable level of risk may be site-specific, contaminant-specific, or a function of the quality of data used to support the risk determination.

- Conduct a test case that factors in NEPA requirenents as appropriate. Get feedback from the Field offices and $H Q$, and fine tune the process accordingly. Guidance from $\mathrm{HQ}$ is needed on whether such a review should go from the Field offices up, or HQ down.

- Adopt media and cross-media approaches; e.g., using emerging Clean Air Act policy development models to focus on other media.

- Move toward a government-wide federal facility approach by establishing liaison with DOD, the U.S. Department of Transportation, and EPA.

\section{$\underline{\text { Supplemental Points }}$}

A viable cleanup methodology can be developed and implemented internally. However, the early cooperation and buy-off of EPA and the states is critical if the method is to be adopted. Early involvement of the regulators is crucial to the planning and development of the methodology. Differences can be addressed through the interagency dispute resolution process and 
negotiation. Other key external factors include public awareness and peer review (e.g., Society of Risk Analysis).

During this working group's presentation to the workshop plenary group, it was suggested that by getting public and professional cooperation and input, the credibility of the methodology and the probability of its adoption will be enhanced. Suggestions included looking for relevant comparisons internationally, and Dr. Curtis Travis was cited as a good resource and proponent of risk assessment (reference: article in December 1990 issue of Science magazine).

RCRA reauthorization will be considered in future arguments for EPA retention of authority over federal facilities under RCRA 3004(a) as well as CERCLA. Then there will be one organization setting cleanup goals, at least for federal facilities, instead of 51 . Los Alamos managers are planning to use risk-based criteria incorporating Future Land Use scenarios to drive cleanup decision making. They want to ensure that their approach agrees with a complex-wide approach. 

ISSUE GROUP - ENVIRONMENTAL MANAGEMENT INTEGRATION

(WASTE OPERATIONS AND ENVIRONMENTAL RESTORATION)

\section{GROUP MEMBERSHIP}

Marvis Aleen, DOE-HQ, EM-20

Richard Dailey, DOE-HQ, EH-231

Bill Fallon (Facilitator), Pacific Northwest Laboratory

Bob Holt, DOE-Richland Operations (Group Leader)

John Hoover, Argonne National Laboratory

Bob Howe, Brookhaven National Laboratory

Walter Sato, DOE-Idaho

\section{ISSUE PRIORITY AND SELECTION}

The group reviewed the three original issues in the issue group and the two additional issues suggested during the issue presentation. The following priority was determined.

1. Treatment, Storage, and Disposa] (TSD) of Waste Generated from Environmenta] Restoration (ER) Activities

2. Waste Minimization

3. Waste Transportation

4. Strategic Value of Special Nuclear Materials (SNMs)

5. Security of Classified Wastes.

There was consensus within the working group that the last two issues were not appropriate issues for this discussion because SNMs are not ER wastes. However, the workshop sponsor pointed out later that the office of Defense Programs (DP) may wish to transfer the SNMs to EM on short notice. This transfer would create serious problems for EM, because custody of SNMs are not currently part of EM's mission or planning. One reviewer observed that SNMs are a major driver for this issue group. Recent court rulings have held that many tons of processing residue at Rocky Flats are wastes and must be treated in some manner. 


\section{ISSUE 1: TSD OF WASTE GENERATED FROM ER ACTIVITIES}

\section{Discussion}

Before addressing the history and suggested action items for this issue, the group discussed it in general terms. Solving the capacity issue related to TSD of wastes generated from ER activities must be given highest priority. Failure to provide adequate capacity will result in schedule slippage and the inability to comply with federal or state regulatory requirements. Projection of TSD needs is required very early in the EM planning process. If data for accurate projections are not available, conservative projections should be made. Resolving the capacity issues with regulators is critical; they must be brought into the planning and made aware of problems from the start.

It was suggested that the issue should be restated as two parallel questions:

1. Does EM-40 adequately identify its TSD needs to Waste 0perations (EM-30)? If so, where and how?

2. Does EM-30 plan for ER waste as we11 as for production-related wastes?

Five examples were cited to illustrate historic TSD problems.

\section{Example \#1}

The 1988 183-H Basin cleanup at Hanford predates the Tri-Party Agreement. A compliance agreement was signed with the Washington Department of Ecology stipulating that drums of mixed waste from the cleanup would go to a central facility. EM has the lead on this activity, and EM-30 is to provide support. However, as EM completes cleanup, EM-30 is unable to receive or accommodate the drums because of a lack of storage capacity. Drums are currently sitting on the ground, and some are corroding. The site is in noncompliance, and the corroding drums pose a health and safety risk. Additional storage construction is about $80 \%$ complete; however, this new construction is being used for other wastes.

\section{Example \#2}

At Idaho National Engineering Laboratory, EM did not define roles for EM-40 and EM-30 for wastes generated during ER activities. Although a waste 
management Activity Data Sheet has been submitted for construction of a new TSD facility for stored transuranic (TRU) wastes, a TSD facjlity may be needed for pre-1971 Rocky flats waste if this facility is built there. This issue was confirmed and clarified during a follow-up conference call. EM-40 will be responsible for facilities needed for TSD of ER-generated waste.

Waste acceptance criteria for the Waste Isolation Pilot Plant does not include pre-1971 TRU waste. Local waste acceptance criteria are developed for wastes to be received by EM-30 facilities but not for ER-generated waste.

\section{Example $\# 3$}

At Hanford, ER activities generate samples that become wastes; e.g., soil drilling residues or groundwater samples. Since enactment of RCRA, there is no proper method for disposing of these samples. Consequently the samples are stored in the lab awaiting disposition. This is not yet an overwhelming problem; however, the labs are not TSD facilities, and the situation does impact the ability to store other materials. Per a $\mathrm{HQ}$ request, an inventory of these stored samples/wastes is under way with a July 1991 completion date scheduled.

However, one reviewer noted that in 1988 EPA issued a final rule (\#53 FR 27290, July 19, 1988) conditionally exempting waste samples used in smal]-scale treatability studies from full regulation under Subtitle $C$ of RCRA. A recently distributed CERCLA Information Brief provides more information on the details of what is and is not covered by the exemption.

\section{Example \#4}

The Land Disposal Restriction Third Third National Capacity Variance will impact the storage time limit. A 2-year variance was given in May 1990, but the clock is ticking. DOE-HQ is working on a DOE-wide case-by-case extension, and Field offices may also choose to initiate individual case-by-case extensions. 


\section{Example \#5}

The bulk of Brookhaven National Laboratory's (BNL) wastes will be generated during remedial implementation (after 1995). Despite an existing TSD facility, there is a need to define EM-40/EM-30 logistics.

Suggested Action Items

The following action items were recommended to address the TSD issue.

- Develop a current complex-wide inventory and a projection of future inventories of the quantities and nature of ER wastes that will require TSD.

- Update the National Compliance Report on Mixed Wastes.

- Conduct a complex-wide assessment of TSD capacity and technology, including the applicability of available technologies.

- Initiate an annual site planning review process to formulate integration of EM-30 and EM-40 TSD activities.

- Assess the shortfall between what TSD capacity is available and what is or will be needed.

- Develop a strategy to address and remedy the projected shortfall. Such a strategy might include ER activity slowdown or phases, prioritized technology development and deployment, renegotiation of agreements, and requests and justifications for increased ER budgets .

Two other actions were cited as being potentially helpful for integrating waste operations and environmental restoration.

- Factor results of DOE's Reconfiguration Study into EM-30 and EM-40 strategies.

- Crosswalk and integrate DOE Orders 5400.4 and 5820.2A.

\section{ISSUE 2: WASTE MINIMIZATION}

\section{Discussion}

Before the small group report on this issue was given, the workshop sponsor commented that it was of particular concern. Specifically, he observed that DOE cannot continue with the institutional storage of everincreasing quantities of materials. It is essential that steps be taken to 
put these inventories into productive use whenever possible. In cases where productive use is impossible, the materials should be economically and permanently disposed of, preferably without DOE custodianship. Ray Greenberg has been designated the EM-40 waste minimization representative. The sponsor also pointed out the issue of who is to be responsible for the TSD of EM-40 wastes. At the time of the workshop it was thought that EM-40 would be given responsibility for the TSD of all wastes generated from EM activities.

The group agreed that there was little or no applicable waste minimization history, per se, within the ER context. However, the group identified the following examples of waste minimization activities from an operations perspective and agreed that they may have future applicability to ER activities.

- Rocky flats has conducted a soil volume reduction project.

- Hanford has succeeded with several "product substitution activities." For example, in 1990 Hanford began using nonlisted paint thinners rather than listed thinners, thereby reducing the overall volume of listed wastes.

- BNL is investigating use of nonhazardous decontamination fluids, thereby reducing mixed wastes. Also improved drilling protocols and methods may reduce volume of hazardous and mixed wastes.

- The Army routinely uses benchtop degreasing units. These units are more economical than larger units and may be applicable to DOE needs. The U.S. Army Corps of Engineers Toxic and Hazardous Materials Agency (USATHAMA) would be the appropriate point of contact.

\section{Suggested Action Items}

The following action items were recommended to address the waste minimization issue.

- Explicitly define the role and goals of waste minimization within the ER program.

- Canvass other agencies regarding waste minimization activities at remediation sites.

- Conduct a complex-wide survey to document and locate reusable material inventories and ongoing ER waste reduction processes and procedures. 
- Canvass the private sector regarding decontamination and decommissioning (D\&D) waste minimization strategies.

- Initiate an annual site planning review process to formulate integration of EM-30 and EM-40 waste minimization activities.

- Support EM-50 development of ER waste minimization procedures; e.g., separation of hazardous components from soils and separation of recyclable materials.

- Promulgate a policy that establishes whether in situ stabilization constitutes waste minimization.

- Develop evaluation models for waste minimization economic analysis.

- Apply the technical expertise that was developed through the Plutonium Recovery Modification Project to DOE's other TSD, waste minimization, and D\&D missions.

Supplemental Points

- EPA's regulatory perspective may have a bearing on what DOE does. In particular, EPA does not view volume reduction (after the fact) as equivalent to waste minimization (before the fact).

- DOE'S R\&D programs should consider EM as a key customer. R\&D * efforts and products should address EM's current and future needs.

- There is a need to integrate EM-30 planning with EM-40 waste minimization/reduction goals and to incorporate this integrated approach into the Programmatic Environmental Impact Statement (PEIS) and site-wide EISS.

\section{ISSUE 3: WASTE TRANSPORTATION}

The group considered this issue but concluded that it lacked sufficient experience or expertise to address it adequately. It was recommended that appropriate staff from EM-50 provide input for this issue. 


\section{ISSUE GROUP - IMPLEMENTATION OF AGREEMENTS/DOCUMENTATION}

\section{GROUP MEMBERSHIP}

John Andrews, DOE-Albuquerque

Jim Bauer, Westinghouse Hanford Company (Group Leader)

Lisa Green, DOE-Idaho

Joel Hebdon, EG\&G, Idaho

Fraser Lockhart, DOE-Rocky Flats

Carolyn Osborne, DOE-HQ, EH-25

Bob Quinn (Facilitator), Pacific Northwest Laboratory

\section{ISSUE PRIORITY AND SELECTION}

The group reviewed the three issues originally included within this issue group:

- Programmatic Environmental Impact Statement (PEIS)

- Federal Facility Agreements (FFAs) and Interagency Agreements (IAGs)

- Interagency Relations.

An additional issue group, Future Land Use, was recommended for this group's consideration. The amended list of issues, in the order in which they were discussed, was

1. PEIS/Future Land Use

2. Implementation of FFAs/IAGs

3. Interagency Relations.

\section{ISSUE 1: PEIS/FUTURE LAND USE}

\section{Discussion}

The PEIS was mandated following a successful lawsuit against DOE by the Natural Resources Defense Council and others. As it is currently being developed, the PEIS reflects DOE's need to establish a unified cleanup strategy and its desire to obtain public comment and consensus. 
A Notice of Intent was issued in 0ctober 1990, and public scoping meetings were recently completed. EH proposed guidance (NEPA strategy) in october that described the role of PEISs in the overall NEPA process. Basically, the PEIS is the tip of a pyramid with site-wide EISs and Environmental Assessments (EAs)/EISs for individual cleanup actions/CXs below it. For cleanup actions, EAs and CXs are expected to represent $75 \%$ to $90 \%$ of NEPA documentation. EM did not extensively comment on the policy.

The group discussion delineated a number of subissues associated with the PEIS/Future Land Use issue. These included the following:

- A contractor has not yet been selected to develop the PEIS. DOE's National Project Manager left the position 6 months ago and, at the time of the workshop, had not yet been replaced. In general, staffing for this effort at both the $\mathrm{HQ}$ and field levels is greatly deficient.

- EM lacks an overall "game plan" for the PEIS compared to other efforts such as the Complex Reconfiguration PEIS. One reason for this planning deficiency is the institutional experience in older offices such as DP, compared to the relatively new EM organization.

- HQ wanted standardization of the scoping presentations. Therefore, there was a lack of Field Office input on how best to deal with the public interest groups active in each location where scoping meetings are held. Further, the scoping process as conducted did not a 1 low the public to get any immediate feedback from DOE. In addition, there is a perception by the public that the PEIS will delay cleanup.

- The role of the Field Offices in the development of the PEIS has not been defined. HQ has initiated weekly conference calls with Field offices, but information has not been properly disseminated.

- The pyramid described in the EH proposed guidance is being driven from the bottom (EAS/CXS) as compared to the top (PEIS). A ROD for the PEIS is not scheduled to be signed until FY 1993 (most believe that schedule to be unattainable). On the other hand, EAs, CXs, and even EISs are being developed at a much faster pace. Therefore, the PEIS is not serving as a general framework for other decisions.

- The PEIS needs to be better integrated with actions required under RCRA and CERCLA. EPA is questioning why we need to do a PEIS (or other NEPA reviews) because the work is covered by these two laws. 
By definition, all decisions made before signing the PEIS ROD are "interim." It is unlikely that the regulators will be comfortable with this designation.

- It is unclear how future land use will be considered within the development of the PEIS. The designation of use will be an important driver in the development of cleanup levels.

\section{Suggested Action Items}

The following action items are recommended in support of this issue. Specific responsible parties are noted in parentheses where necessary.

- Provide better guidance to the Field offices by answering the following questions: 1) What is the relationship between the PEIS and site-specific EISs and where do the handoffs between the two take place? 2) What is expected from the field in the development of the PEIS? 3) What resources will be needed at the HQ and field levels to develop the PEIS?

- Improve communication both internally and externally.

- Direct a public outreach program on cleanup/PEIS.

- Clearly identify and communicate the goals of the PEIS to the public and states. DOE should not go overboard in an attempt to show that no decisions are preordained. The PEIS should identify preferred alternatives or even a single preferred alternative.

- Develop a firm concept of what pre-PEIS ROD decisions represent (i.e., which ones will have to be revisited after the PEIS ROD).

- Identify how far the Field Offices can go under CERCLA/RCRA and remain in compliance with NEPA. Meet with EPA-HQ to discuss integration of RCRA and CERCLA with NEPA, assist EPA in drafting guidance on the concept, and have EPA-HQ disseminate the guidance to its Regional offices.

- Assess and address the following concerns: 1) the potential impact of current compliance agreements on the PEIS and vice versa, 2) the effect of the PEIS on negotiated schedules, and 3) the facilities needed to implement cleanup.

- Develop a long-term general land-use policy and fully integrate it into the PEIS. 


\section{ISSUE 2: IMPLEMENTATION OF FFAS/IAGS}

\section{Discussion}

Interagency agreements are required under the Superfund Amendments and Reauthorization Act (SARA) for all federal facilities on the NPL. Most FFAs/IAGs to date have been entered into "voluntarily, " because they were done so before the statutory deadline.

DOE and EPA negotiated model language in 1988 to be used to facilitate specific negotiations. The language has been used extensively to date. There is an ongoing effort to renegotiate parts of the model provisions, and a letter has been sent to EPA.

FFAs/IAGs are a method of integrating the requirements of CERCLA and RCRA and obtaining an agreement from DOE/EPA/states on schedules, roles, etc.

Schedules associated with FFAs/IAGs should specify the regulatory review periods for deliverables. The agreements should stipulate that if these periods are exceeded by the regulatory agencies the schedules may be revised to the extent that the periods were exceeded.

The group discussion delineated a number of subissues associated with the implementation of IAGs/FFAs. These included the following:

- The collective commitments of all agreements are unknown. A nationwide evaluation of all agreements has not been performed. Resources needed to implement the agreements have not been identified. A better understanding of the financial commitments being made is needed before entering into agreements.

- There is not enough clearly defined guidance on how to negotiate agreements. Model language, assorted correspondence, and negotiation strategies are not enough. What is needed is a strong, consistent knowledge base, made avajlable to all negotiators. In addition, Field Offices need consistent guidance on how to deal with the States and a greater flexibility to renegotiate agreements.

- Currentiy, the Operations Office Manager signs the agreements, but the ultimate control is held by $\mathrm{HQ}$. The operations office has all of the responsibility and none of the authority. There remains a question of how HQ conments must be addressed and who has the final say. 
- There is a disconnect between the 2-year budget projections and the requirements within agreements.

\section{Suggested Action Items}

The following actions were suggested to facilitate the negotiation of agreements.

- Ensure that the correct individuals from Field offices and HQ are included on the negotiation teams.

- Develop a consistent policy regarding how far a DOE negotiator can go when dealing with a state, particularly those states that are claiming RCRA authority at an NPL site.

- Update the model language to include the addition of the ability to renegotiate issues.

Related activities would include

- Analysis of the commitments made under agreements to date along with the development of a data base to track these and future commitments.

- Establishment of a training program on how to negotiate agreements (EH-23 is currently providing a training course on negotiation skills; therefore, it is recommended that individuals involved in negotiations be strongly encouraged to attend.)

- Development of guidance on the resources and infrastructures (e.g., manpower, etc.) needed to implement agreements.

The group recommended that a number of activities be initiated with EPA.

- Obtain EPA/state buy-in on the National Prioritization System being developed for ER activities. This endorsement will allow the use of the system to be fully incorporated into future agreements.

- Work with EPA to develop a better method of measuring success under agreements and within the remedial program in general. To date, success has been calculated by counting the number of documents completed rather than through substantive yardsticks such as total risk reduction.

- Urge EPA to make greater use of the Office of Management and Budget A-106 process to assist DOE in obtaining the funding needed to comply with the schedules contained within agreements. 
Other suggested actions, more internal to DOE, included

- Expeditiously finalize the EM-1 and EM-40 Program Management Plans, as well as any corresponding plans at the field level.

- Quickly develop a policy on the resolution of comments on primary documents (HQ and Field offices).

\section{Supplemental Points}

DOE negotiators should ensure that all parties fully understand the exact scope of the agreement before proceeding with its execution. The needs of agreements should drive the activities undertaken by EM-50 rather than "doing research for research's sake." External groups and individuals should be used to provide a peer review of documents. These reviews would also provide the regulators with an independent rationale for the remedy selection made by both agencies.

\section{ISSUE 3: INTERAGENCY RELATIONS}

\section{Discussion}

Other government branches such as DOD share very similar problems and may have already identified some potential solutions. In addition, these agencies may have already established precedents under which DOE must operate. Also, the combined efforts of multiple agencies on the resolution of an issue that affects them is clearly preferable to a more fragmented approach. Despite these advantages, very little interaction among the agencies has occurred to date. This lack of coordination has already led to difficulties at sites such as Weldon Spring. No common decision tools exist nor is there any interlinking of data bases.

\section{Suggested Action Items}

The group recommended a multistep approach to foster greater coordination among DOE and the other agencies.

1. Identify common issues and interests.

2. Establish one or more interagency working groups to address the issues. Where appropriate, the agencies should develop a common front to present to EPA and others. 
3. Coordinate the combined commitments made by each agency (TSD needs, etc.).

4. Establish data links with EPA, DOD, and others, particularly in situations such as sites in proximity to one another.

Additional, related action items were:

- Hold planning and technical meetings with the regulators to provide coordinated direction to the ER program and to resolve issues before they become problems. Establish a technical review committee composed of DOE and regulatory personnel at each Field office to receive comments on plans and studies before a primary or secondary document is drafted. Individual committee members should be responsible for ensuring their input reflects a total state, EPA, or DOE position. 



\section{CONCLUSIONS AND RECOMMENDATIONS}

This report synthesizes information generated through four forums: 1) DOE Field Office conference calls, 2) DOE HQ interviews, 3) workshop group discussions, and 4) incorporation of review comments. Collectively, the opinions expressed indicate that DOE and $M \& O$ personnel are highly motivated in their efforts to implement DOE's environmental restoration program, yet they are greatly impeded by the types of issues discussed in this report.

Many of the issues or action steps described in this report have been discussed previously, particularly in EM's Five-Year Plan and draft Program Management Plans. However, many workshop participants indicated that the synergy generated by interacting directly with colleagues from across the DOE complex provided fresh perspectives and enthusiasm for addressing familiar problems. Site personnel learned that many of their concerns are, in fact, complex-wide concerns. The fundamental recommendation from this exercise is to maintain and capitalize on this enthusiasm. This point was made by one of the workshop participants in his review of this report:

\footnotetext{
"... the subject workshop was extremely useful as the first major step in identifying pressing regulatory and institutional concerns that impact the environmental restoration (ER) program. However, the enthusiasm presented by the participants at the workshop must be sustained in order to effectively follow up and resolve the ER issues identified."
}

During the planning stages of this exercise, concerns were voiced that the regulatory and institutional issues confronting EM were so extensive that it would be difficult to address even a subset of them meaningfully during a two-day workshop. This concern highlights a key point, namely that the exercise was not designed to resolve issues. Rather, the objective was to generate ideas on concrete steps that could be implemented toward resolving complex-wide issues. The value of this exercise will be realized incrementaliy, and in direct proportion to the degree that the suggested steps are evaluated, refined, and implemented. Indeed, if the suggested steps are followed and built on, the exercise itself can help address one of the key workshop issues; that is administrative requests that drain field resources without any apparent value added. 
Rapid implementation of all of the proposed action steps is unrealistic. However, a deliberate, incrementa1 approach could be devised that would demonstrate significant short-term progress and would also be conducive to creating long-term confidence in and enthusiasm for a complex-wide issue resolution process. Such an approach would entail the following steps:

1. Organize implementation and communication teams (these could also be called issue resolution teams) for each of the five issue groups discussed at the December workshop. Teams would operate in coordination with appropriate EM, EH, and Field Office staff in refining, prioritizing, sequencing, and implementing selected actions proposed at the workshop. A number of individuals or organizations have already expressed a willingness to serve on such teams (Appendix H).

2. Develop a fairly simple workshop recommendation tracking and reporting system. The primary function of this system would be to maintain the interest and enthusiasm that was in evidence at the workshop. Workshop participants, and others as appropriate, would receive periodic feedback on progress being made towards issue resolution, action steps that are being implemented, and other information of interest to those concerned with the resolution of $E R^{\prime} s$ regulatory and institutional issues. Input to this system could be provided by the teams described above. This system should be designed and maintained expressly to provide the workshop network with concrete evidence of progress and upper management's commitment to continued progress.

3. At the workshop, only a subset of the issue groups identified during the conference calls and interviews was discussed. The remaining issues must also be addressed. Steps towards resolving them should also be identified and implemented. However, it is unlikely that a similar workshop to address the remaining issues would generate the same level of interest and energy, at least in the near term. These issues could, however, be addressed through white papers or by small working groups convened to brainstorm the issue in a manner similar to that done at the workshop. Moreover, if this were done, it would provide an interesting comparison of the relative merits, quality, and costs of parallel products generated by different mechanisms. This comparison could be of considerable interest to other DOE offices contemplating topical workshops. 


\section{LIST OF ACRONYMS AND INITIALISMS}

ARARs applicable or relevant and appropriate requirements

BNL Brookhaven National Laboratory

CEQ Council on Environmental Quality

CERCLA Comprehensive Environmental Response, Compensation and Liability Act

CX Categorical Exclusion

D\&D decontamination and decommissioning

DOE U.S. Department of Energy

DOD U.S. Department of Defense

DP Defense Programs

DQO data quality objectives

EA Environmenta1 Assessment

EH Office of Environment, Safety and Health

EIS Environmental Impact Statement

EM Office of Environmental Restoration and Waste Management

EM-30 Office of Waste Operations

EM-40 Office of Environmental Restoration

EM-43 Program Support Division, EM-40

EM-50 Office of Technology Oevelopment

EPA U.S. Environmenta1 Protection Agency

FFA Federal Facility Agreement

FS Feasibility Study

FUSRAP Formerly Utilized Sites Remedial Action Program

GC Office of General Counse1

HQ Headquarters 
IAG Interagency Agreement

M\&0 management and operations

NE Office of Nuclear Energy

NEPA National Environmental Policy Act

NPL National Priorities List

NRC U.S. Nuclear Regulatory Commission

PEIS Programmatic Environmental Impact Statement

PNL Pacific Northwest Laboratory

RAAS Remedial Action Assessment System

RCRA Resource Conservation and Recovery Act

R\&D research and development

RI Remedial Investigation

ROD Record of Decision

SARA Superfund Amendments and Reauthorization Act

SNM special nuclear materials

TRU transuranic

TSD treatment, storage, and disposal

UMTRAP Uranium Mill Tailings Reclamation Action Program 


\section{APPENDIX A}

\section{PRELIMINARY ISSUE IDENTIFICATION AND CHARACTERIZATION}


APPENDIX A

\section{PRELIMINARY ISSUE IDENTIFICATION AND CHARACTERIZATION}

The immediate objeotive of the Field office conference calls and HQ meetings was to generate a comprehensive list of issues or problems that posed impediments to progress in the eyes of responsible managers and support professionals, and thus the major issues confronting EM-40. The strategic objective was to generate a data base of site issues that could be clustered into complex-wide issue groups for discussion at a follow-up workshop. It was explicitly stated that information collected during the calls and meetings would remain anonymous in terms of the individuals and sites from which it originated.

\section{FIELD OFFICE CONFERENCE CALLS}

EM-40 provided PNL with a list of environmental restoration program contacts (Appendix C) at each of the following DOE field or operations offices: Albuquerque, Chicago, Idaho, Nevada, Oak Ridge, Richland, Rocky Flats, Livermore, and Savannah River.

The issues identification exercise was announced in a letter sent from the Associate Director, EM-40 (Appendix D) to each of the nine contacts. Subsequently, PNL staff telephoned each program contact to answer questions regarding the exercise, schedule the conference calls, and learn which DOE and Management and Operations (M\&O) contractor personnel were nominated by the program contact to participate in the conference calls.

The conference calls were made between October 17 and 29 . The number of participants ranged from 4 to 16 . Conference call participants addressed the questions found in the attachment to Appendix D. During the calls, two to four PNL staff members transcribed the conversations. After the last call, a follow-up letter (Appendix D) was sent to each contact thanking them and requesting that they identify individuals who would be attending the December workshop. 
Conference call participation met the objective of capturing complexwide input. Approximately 70 individuals participated. Appendix D contains a list of the participants by Field Office affiliation.

- HEADQUARTERS INTERVIEWS

To complement the Field office input, interviews were conducted with selected HQ staff. The HQ staff were identified and notified of the exercise by internal memoranda. These interviews were conducted in washington D.C., and Germantown, Maryland. The protocol for the interviews was similar to that used during the conference calls. Interviewees were asked to specify highest priority issues and their current coping mechanisms.

The combined transcribed notes from the calls and interviews amounted to about 60 pages. The PNL planning team analyzed and summarized these notes. Recorded comments were categorized as being either an issue, information that supports or otherwise characterizes an issue, or a suggested action that could address the issue. This process yielded 36 specific issues, which were clustered into 13 issue groups and organized into issue summary documents (Appendix E). 


\section{APPENDIX B}

\section{REGULATORY AND INSTITUTIONAL ISSUES WORKSHOP}


APPENDIX B

\section{REGULATORY AND INSTITUTIONAL ISSUES WORKSHOP}

A workshop announcement and logistics package was prepared and sent to participants by the Associate Director, EM-40 (Appendix F). Logistics required that workshop attendance be limited. To ensure balanced participation, each Field Office was asked to send one DOE representative and one M\&O contractor representative. Some Field offices requested additional participation because of the number of geographically dispersed sites under their cognizance. Other Field offices requested that representatives from their legal staff also attend. These requests were accommodated. The Office of General Counsel (GC) was also represented at the workshop.

of 43 attendees, 25 were from Field Offices, and 18 were from HQ. Headquarters representation included 11 from EM, six from EH, and one from GC. Field representation included ten from DOE, nine M\&O contractors, and six National Laboratory personne1.

Workshop activities are descríbed in detail in Appendix A. Introductions, presentation of issues, voting, and formation of working groups were completed during the first half of the first day. Opening remarks were made by senior EM and EH representatives. An overview of the 13 issue groups was presented by the lead PNL facilitator. Participants suggested additional issues or revisions and were then asked to prioritize the 13 issue groups with the objective of selecting five for detailed discussion. Guidelines for voting on issue priority were:

- feasibility

- conduciveness to short-term progress

- primarity a DOE matter

- health and safety risk

- instincts.

The results of this voting were: 


\begin{tabular}{rll} 
Rank & Score & \multicolumn{1}{c}{ Title } \\
\cline { 3 - 3 } 1 & 374 & Regulatory Streaml ining \\
2 & 329 & General DOE Guidance and Administration \\
3 & 309 & Cleanup Levels \\
4 & 299 & Environmental Management Integration \\
5 & 292 & Implementation of Agreements/Documentation \\
6 & 275 & Regulatory Integration \\
7 & 271 & Cleanup Authority and Consistency \\
8 & 229 & DoE Infrastructure \\
9 & 202 & Risk Management \\
10 & 181 & Information Systems \\
11 & 177 & U.S. Environmental Protection Agency \\
12 & 168 & (EPA) Issues \\
13 & 121 & Future Land Use \\
& & Community Relations Programs
\end{tabular}

Formation of working groups was voluntary within suggested guidelines to ensure that groups were numerically balanced and that each included a mix of HQ, Field Office, and M\&O contractor staff. Before convening into working groups, participants were given a demonstration on the use of storyboarding as a workshop tool. Storyboarding was used for this exercise because it offers an effective technique for brainstorming and for quickly capturing, assembling, prioritizing, reviewing, and revising ideas as they are being generated by a group. Each group was provided storyboards, pens, pins, and index cards.

\section{WORKING GROUP DISCUSSIONS}

Each group selected a leader to initiate discussion and present an oral report plenary group. Each group included a PNL facilitator whose primary role was to keep discussions moving and focused. Each group was given suggested procedures for approaching its task (Appendix G). The suggested approach was to

1. Prioritize the individual issues within the issue group.

2. Starting with the highest priority issue, elaborate on its history: e.g., cite specific examples of the problem, what has been or is being done towards resolving it; by whom, when, what results ensued; what problems were encountered; and what products are available. 
3. Develop a list of sequential action items that could be implemented at $H Q$ or in the field to begin to address and resolve the issue.

4. Select the next highest priority issue and proceed as before.

Group work continued through the end of the first day.

\section{PRESENTATION OF WORKING GROUP REPORTS TO PLENARY SESSION}

On the second day, group leaders reported on the results of their work to the plenary group. Feedback from the plenary group was recorded by faci1itators for inclusion in the written report.

The storyboards generated by the working groups as well as notes taken during their presentation were the basis for this written report. Draft reports were circulated to all participants for final comments and ideas. All workshop participants (Appendix G) were thanked for their contributions in a letter from the Associate Director, EM-40 (Appendix G). 



\section{APPENDIX C}

ENVIRONMENTAL RESTORATION PROGRAM OPERATIONS OFFICE PRINCIPAL CONTACTS 


\section{APPENDIX C}

ENVIRONMENTAL RESTORATION PROGRAM

OPERATIONS OFFICE PRINCIPAL CONTACTS

Rich Sena

Project Manager, Environmental

Restoration Project office

U.S. Department of Energy

Albuquerque Operations office

P.0. Box 5400

A lbuquerque, NM 87115

Phone: $505-845-6397$

FTS: $845-6307$

FAX: $\quad 845-4234$

Ver: $845-4887$

Joe 1 Haugen

Waste Managenent Project

U.S. Department of Energy

Chicago Operations office

9800 South Cass Avenue

Chicago. IL 60439

Phone: 798-972-2093

FTS: $972-2093$

FAX: $\quad 972-2206$

Ver : $972-2209$

Jerry Lyle

Director, Environmental Restoration

Division

U.S. Department of Energy

Idaho Operations office

785 Doe Place

Idaho Falls, I0 83462

Phone: 208-526-1148

FTS : $\quad 583-1148$

FAX: $\quad 583-1184$

Ver: $583-1952$

Joseph H. Fiore

Director, Environmental Restoration and Waste Management Division

U.S. Department of Energy

Nevada Operations Office

P.O. Box 98518

Las Vegas. NV 89193-8518

Phone: 702-295-7063

FTS: $\quad 575-7063$

FAX: $\quad 575-1810$

Ver: $575-7063$

Robert Sleenan

Director. Environmental Restoration

Division

U.S. Department of Energy

Oak Ridge Operations office

P.0. Box 2801

Oak Ridge. TN 37831

Phone: 615-576-9715

FTS: $626-9715$

FAX: 626-1063

Ver:

\author{
Roger Freeberg \\ Chief. Environmenta T Restoration \\ Branch \\ U.S. Department of Energy \\ Richland Operations office \\ 825 Jadwin Avenue \\ P.O. Box 550 \\ Richland, WA 99352 \\ Phone: $509-376-7167$ \\ FTS: $444-7167$ \\ FAX: $444-7818$ \\ Ver: $444-7167$ \\ Rich Schassburger \\ Deputy Oirector, Environmenta 1 \\ Restoration Division \\ U.S. Department of Energy \\ Racky Flats office \\ P.O. Box 928 \\ Golden, CO 80492-0928 \\ Phone: $393-966-4888$ \\ FTS: $345-4888$ \\ FAX: $\quad 345-2256$ \\ Ver: $345-4888$ \\ Joe Cullen \\ Branch Chief, Environmenta 1 \\ Restoration Program \\ U.S. Department of Energy \\ Livemore Site office \\ P.0. 80x 808/L-57 \\ Livermore, CA 94550 \\ Phone: $415-423-4340$ \\ FIS: $\quad 543-4340$ \\ FAX: $\quad 543-4279$ \\ Ver: $\quad 543-4340$ \\ Lewis Goidell \\ Director. Environmental \\ Restoration Division \\ U.S. Department of Energy \\ Savannah River Operations office \\ P.O. Box A \\ Aiken, SC 29802 \\ Phone: $863-725-3966$ \\ FTS: $239-3965$ \\ FAX: $\quad 239-8434$ \\ Ver: $239-3966$
}




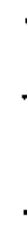




\section{APPENDIX D}

CONFERENCE CALL/INTERVIEH INFORMATION 
APPENDIX D

\section{CONFERENCE CALL/INTERVIEW INFORMATION}

This appendix contains information related to the first part of the issues exercise, conference calls to Fjeld offices and interviews with DOE Headquarters staff. It contains the following items:
Meno from EM-40 Introducing Exercise
D.2
Letter to Conference Call Participants
D. 8
Field Office Conference Call and Headquarters Interview Participants
D. 10 
DATE:

AEPLY TO

ATTN OF: $E M-43$ (W. Wisenbaker 3-2950)

SUBJECT: Identification of Regulatory and Institutional Issues Impacting Conduct of Environmental Restoration Activities

TO: Distribution

Many regulatory and institutional issues have arisen because of the centralization of and increased emphasis on environmental restoration, waste management, and technology development activities at Department of Energy Headquarters (DOE-HQ). The Office of Environmental Restoration (ER) recognizes that to achieve its program goals, it will be necessary to identify and resolve those issues that impede progress.

As a first step, ER is sponsoring an exercise to identify major regulatory and institutional issues that are impeding or may impact the conduct of environmental restoration activities at both $H Q$ and Field office levels. It is my expectation that the exercise will also complement and support policy activities involving the Office of Environment, Safety, and Health (EH). The product of the exercise will be a report to my office listing ali issues of concern and providing in-depth analysis of those regulatory and institutional issues of highest priority.

I have tasked the Pacific Northwest Laboratories to coordinate this effort as a continuation of policy work they have done for EH. To support this effort, I am requesting that you designate qualified DOE and Management and Operations (M\&O) contractor representatives from your Field office to participate in an issues identification exercise. The exercise will be conducted in two parts: a conference call to each site to gather preliminary data and a 2-day meeting in the Washington, D.C., area on December 5 and 6 . Specific details about these events are found in the attachment. Within a week, you will be contacted by a member of the ER project tean conducting the exercise and asked to identify the individuals you have designated to participate in the conference call.

This exercise will mark the beginning of an ongoing process of issue identification, tracking, and resolution. Results are intended to benefit environmental restoration work across the DOE complex. Although participation in this initial exercise will be limited to DOE and M\&O contractor staff, it is expected that the results will serve as a basis for subsequent activities with broader representation.

I look forward to working with you and your staff on this important exercise. If you have questions, please contact William (Bill) Fallon, (202) $646-7787$.

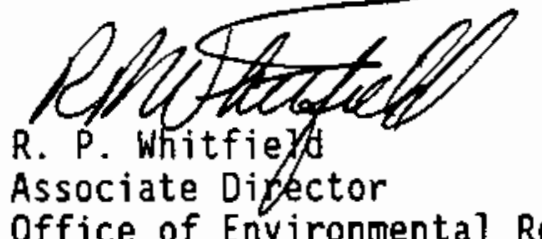

Office of Environmental Restoration 


\section{ATTACHMENT}

\section{GENERAL INFORMATION AND INITIAL INSTRUCTIONS FOR ISSUES EXERCISE}

The Office of Environmental Restoration (ER) is sponsoring an exercise to identify and suggest solutions for high-priority regulatory and institutional issues that could impede onsite remediation activities. Regulatory and institutional issues commonly overlap. For clarification, the following definitions are suggested.

Regulatory Issue - - An impediment to progress arising from over apping, conflicting, unclear, flawed, or missing regulatory statutes, directives, or guidance. These issues define the roadblocks arising from the regulatory framework in which the ER program functions.

Institutional Issue - - An impediment to progress based on the need for or weaknesses in 1) communication linkages or operational interfaces, 2) knowing the roles, responsibilities, and authorities of $\mathrm{HQ}$, Field offices, national laboratories, support contractors, states, etc., 3) policy and implementation guidance, or 4) technical quality of work.

In general, the purpose of this exercise is to:

1. Provide an open forum for identifying and broadly characterizing the regulatory and institutional issues that are or will likely be impacting progress in the ER program.

2. Address potential solutions to these issues.

3. Elevate the top issues/potential solutions to senior Department of Energy (DOE) management.

4. Initiate a process for tracking progress on solving these issues. Progress might be impacted at the HQ, Field Office, contractor, or the national laboratories level.

In similar exercises conducted for other Department of Energy (DOE) offices, a two-part approach has been found to offer the most effective use of time and resources. Part 1 will be a conference call to each Field office during which selected staff will be asked to identify regulatory and institutional issues of concern, give specific examples, and discuss how they are currently coping with these issues. The appropriate DOE-HQ staff will also respond to a similar call. Part 2 will be a 2 -day meeting during which participants from each site and DOE-HQ will work through the issues in more detail.

PART 1 - CONFERENCE CALL

The first part of this exercise is preliminary information gathering designed to identify existing and upcoming regulatory and institutional issues that the Field offices are facing in conducting onsite remediation activities. Answers wi]l be used to help structure the December meeting, develop presentation materials, and initiate meeting discussions. It is expected that many common issues exist across the DOE complex, and these will be discussed in the meeting. 
As the principal ER Program contact for your Field office, please select, as soon as possible, up to approximately five individuals from a representative sample of installations under your responsibility. These individuals should be well versed in issues at their installations. Emphasize that the information they provide during the conference call will not be attributed to a specific site or individual, but will be combined with other responses from across the DOE complex to develop clusters of trends or key issues for the subsequent meeting. The following questions will be asked during the conference call:

1. What issues have been encountered at your site that are impeding the progress of environmental restoration activities?

2. Give specific examples of these issues.

3. What new issues are you expecting over the next 2 to 3 years that are likely to be roadblocks to conducting environmental restoration activities?

4. How is your site currently coping with the above (existing and future) issues?

It is suggested that you and your designated respondents prepare for the call in advance by considering these questions. The conference call can include all five individuals you have designated from whom a consensus of the issues can be derived, or you can designate a representative of the group to present the group's views. Although the conference call may precipitate other discussions, the primary objective of the call is for the project team members to record the requested information.

You will soon be contacted by a member of the project staff to answer any questions you may have, record the addresses and phone numbers of individuals you have designated to participate in the conference call, and schedule a time and date for the conference call. The calls will be made during the third week of october.

\section{PART 2 - MEETING}

Part 2 of the exercise is a meeting to be held in the Washington, D.C., area on December 5 and 6 . Please designate two attendees, preferably from among the participants in the conference call. Participation must be limited because of logistics and facilities. The two attendees might include one representative from DOE (preferably yourself) and one from an M\&O contractor. Meeting participants should be well versed in your site's regulatory and institutional issues and be well qualified to diagnose and suggest remedies for these issues.

Based on the results of the conference calls, issues will be grouped in a preliminary manner, and any trends will be examined. During day 1 of the meeting, these issues and their groupings will be augmented and/or modified to reflect the consensus of the participants. Later that day, participants will be asked to select a given issue group and develop supporting 
information with other group members. The information generated will be assembled onto storyboards for review by all meeting participants. (The technique of storyboarding will be used throughout the meeting and taught to participants for their use.) Day 2 will focus on issue solutions and resolutions. A preliminary list of the information to be developed in each group is outlined here.

Tasks

\section{Issue Identification}

This task is designed for each working group to settle on a final list of issues they will scope out for tasks 2 through 5.

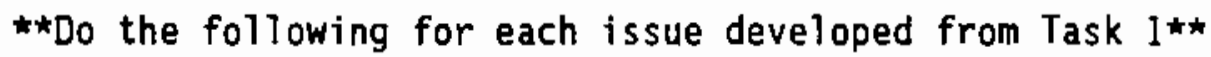

\section{Issue Characteristics}

Issues are important because they impact work progress. Task 2 gives specific examples of situations where work is being impacted. Who is being impacted by the issue?

\section{Why Does Each Issue Exist?}

The group is asked to address the primary and perhaps secondary reasons (causes) why each issue exists.

4. 1ssues' Impact on ER Program

Issues can have many different impacts on the ER Program (e.g., schedules or costs). What do you think the top 1 or 2 impacts are? Roughly quantify if possible.

\section{Issue Prioritization}

With the information gained from tasks 1 through 4 , the group should rank or prioritize all issues.

**Do the following for the top-ranked or highest-priority issues**

6. Potential Solutions

For the top-ranked issues, the group should assess if known solutions exist, what some short- or long-term solutions might be, recommend first steps in working toward a solution, and identify activities that $H Q$ and or the Field Dffices should take to resolve each issue.

7. Time Frame for Resolution

How quickly can measurable progress on these issues be shown? 
OTHER INFORMATION

Participation at the meeting will be limited to DOE-HQ and Field office staff and M\&O contractors. Headquarters participants will be selected from ER and EH. Other attendees will include a limited number of technical and administrative support staff. Despite the limited participation in this initial exercise, it is envisioned that the participants and proceedings would serve as a core for expanded dialogue that could include regulatory agencies, States, regions, tribes, and other concerned parties and organizations.

The agenda and logistics arrangements for the meeting are being prepared. A complete package will be sent to you and to designated meeting attendees. The project team member who contacts you will answer any questions you have about the meeting or the exercise in general. In addition, you can contact one of the following project staff members to answer questions.

William E. Fallon

Project Manager

Pacific Northwest Laboratory

370 L'Enfant Promenade, Suite 900

Washington, D.C. 20024

Phone (202) 646-7787

Fax (202) $646-7838$
Jodi P. Kohlman

Administrative Specialist

Pacific Northwest Laboratory

P.0. Box 999, K6-55

Richland, WA 99352

Phone (509) 376-8407

Fax (509) $376-7716$ 


\title{
Distribution
}

\author{
Rich Sena, AL \\ Joel Haugen, $\mathrm{CH}$ \\ Jerry Lyle, ID \\ Donald Elle, NV \\ Robert Sleeman, OP \\ Roger Freeberg, RL \\ Rich Schassburger, RF \\ Joe Cullen, Livermore Site Office \\ Lewis Goidel1, SR
}


November 5, 1990

Rich Schassburger

Deputy Director

Environmental Restoration Division

U.S. Department of Energy

Rocky Flats office

P.0. Box 928

Golden, CO 80404-0928

Dear Rich:

I would like to thank you for your assistance in coordinating the recent conference call on regulatory and institutional issues impacting ER Program activities. The responses from each of the nine field offices were excellent and collectively they are a graphic delineation of high priority issues from across the complex. The input is now being consolidated into a single 1ist which will be distributed to all conference call participants in the near future. It will also serve as the point of departure for the meeting in Washington D.C. on December 18-19.

To ensure that both the field and headquarters derive the maximum benefit from this exercise it is important that highly qualified and motivated personnel attend the follow-up meeting. For logistical reasons we are requesting that participation be generally limited to two representatives from each field office. Ideally these two would include one DOE representative and one M\&O contractor, both of whom should be well versed in the regulatory and institutional issues of concern to your facility.

May I ask for your further assistance in completing two tasks relative to the meeting participants. First, to the extent possible, finalize the list of DOE and contractor personnel who will be attending the meeting from your field office and fax to me the following information on each of them: name, title, affiliation, mailing address, phone, and fax. My fax number is (202) 6467838 .

Second, given the meeting's proximity to the holidays, urge the attendees to complete their travel reservations immediately. Participants should plan on arriving in Washington on the evening of Monday, December 17 th and departing after $5 \mathrm{pm}$ on Wednesday the 19th. A block of rooms has been reserved at the Holiday Inn in Gaithersburg, Maryland. We will be sending materials describing the meeting and logistics to the participants in the near future. 
Thank you again for your assistance in this exercise. I am increasingly confident that your investment and involvement will bear long-term benefits both for your facilities and for the DOE complex nationwide. Do not hesitate to call me at (202) $646-7787$ should you or the meeting participants have any questions.

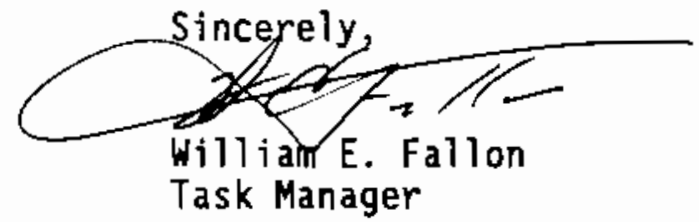




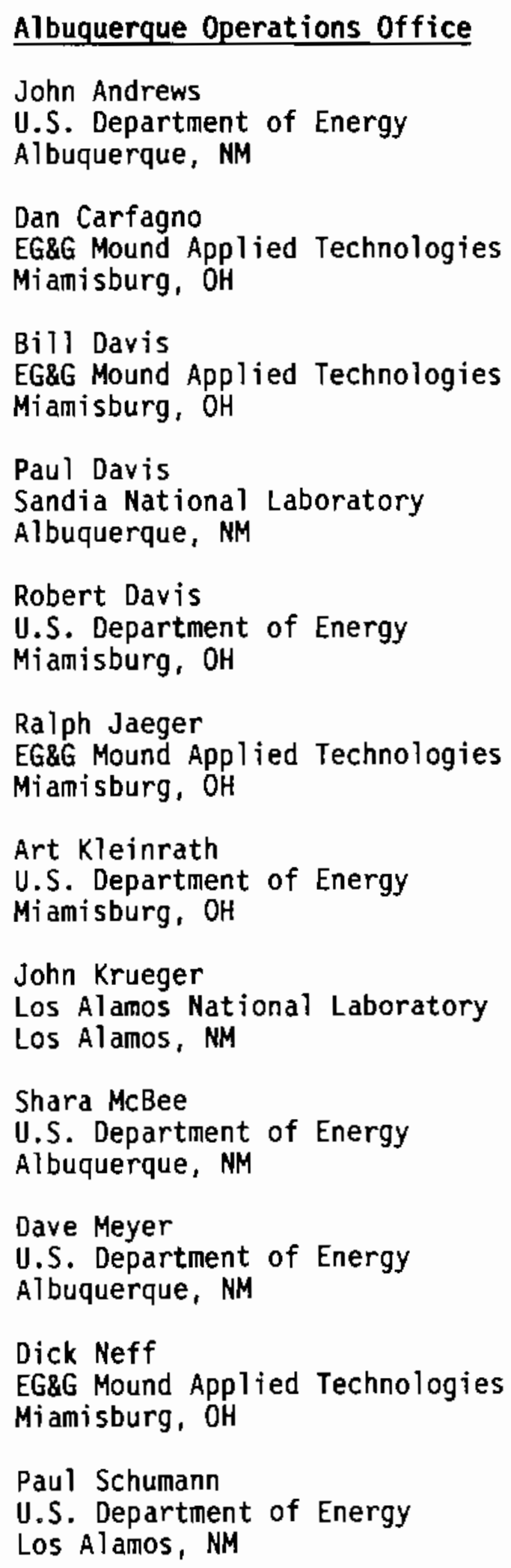


Rich Sena

U.S. Department of Energy

Albuquerque, NM

Lars Soholt

Los Alamos National Laboratory

Los Alamos, NM

Mike Usher

EG\&G Mound Applied Technologies

Miamisburg, $\mathrm{OH}$

Sandy Wagner

Los Alamos National Laboratory

Los Alamos, NM

\section{Chicago Operations Office}

Thomas Bajllieul

U.S. Department of Energy

Argonne, IL

Mike Clancy

Brookhaven National Laboratory

Upton, NY

Sue Davis

Brookhaven National Laboratory

Upton, NY

Len Emma

Brookhaven National Laboratory

Upton, NY

Susan Heston

U.S. Department of Energy

Argonne, IL

Ronald Kolzow

Argonne National Laboratory

Argonne, IL

Lowel) Mathison

Ames Laboratory

Ames, IA

Jan Naidu

Brookhaven NationaT Laboratory

Upton, NY

Gail Penny

Brookhaven National Laboratory

Upton, NY 
Vicki Prouty

U.S. Department of Energy

Argonne, IL

Bill White

U.S. Department of Energy

Argonne, IL

\section{Idaho Operations office}

0 . K. Earle

Westinghouse Idaho Nuclear Company, Inc.

Idaho Falls, ID

D. B. Engelman

EG\&G Idaho, Inc.

Idaho Falls, ID

Lisa Green

U.S. Department of Energy

Idaho Falis, ID

Ira K. Hall

EG\&G Idaho, Inc.

Idaho, Falls, ID

Mike Holzemer

Argonne National Laboratory - West

Idaho Falls, ID

Gary Marshall

Argonne Nationa1 Laboratory - West

Idaho Falls, ID

Walter N. Sato

U.S. Department of Energy

Idaho Falls, ID

R. G. Thompson

EG\&G Idaho, Inc.

Idaho Falls, ID

Dee Williamson

Westinghouse Idaho Nuclear Company, Inc.

Idaho Falls, ID

Lee C. Witbeck

Argonne National Laboratory - West

Idaho Falls, ID 


\section{Livermore Site Office}

\section{Susan Brechbill}

U.S. Department of Energy

Oakland, CA

William Isherwood

Lawrence Livermore National Lab

Livermore, CA

Sus $i$ Jackson

Lawrence Livermore Nationa] Lab

Livermore, CA

Albert Lamarre

Lawrence Livermore National Lab

Livermore, CA

Sandy Leo

Sandia National Laboratories

Livermore, CA

William McConachie

Lawrence Livermore National Lab

Livermore, CA

Janet Tulk

Lawrence Livermore National Lab

Livermore, CA

\section{Mevada Operations Office}

Tim Buqo

Earth Technology Corp.

Las Vegas, NV

Joe Fiore

U.S. Department of Energy

Las Vegas, NV

Jim Littlejohn

U.S. Department of Energy

Las Vegas, NV

Steve Mellington

U.S. Department of Energy

Las Vegas, NV 


\section{0ak Ridge Operations Office}

Linda Dolan

Martin Marietta Energy Systems, Inc.

Oak Ridge, TN

Nelson Lingle

U.S. Department of Energy

Oak Ridge, TN

John Sweeney

U.S. Department of Energy

Oak Ridge, TN

\section{Richland Operations Office}

Roger Freeberg

U.S. Department of Energy

Richland, WA

Robert Holt

U.S. Department of Energy

Richland, WA

Roger Landon

Westinghouse Hanford Corporation

Richland, WA

Barbara D. Williamson

Westinghouse Hanford Corporation

Richland, WA

\section{Rocky Flats Area Office}

Gary Anderson

EG\&G

Rocky Flats, Co

Michael Arndt

EG\&G

Rocky Flats, CO

Scott Grace

U.S. Department of Energy

Rocky Flats, Co

Thomas Greenyard

EG\&G

Rocky Flats, CO 
Frazer Lockhart

U.S. Department of Energy

Rocky Flats, $\mathrm{CO}$

\section{Savannah River Operations Office}

Roger Duke

Westinghouse Savannah River Co.

Aiken, SC

Mike Dukes

Westinghouse Savannah River Co.

Aiken, SC

Lewis C. Goidell

U.S. Department of Energy

Aiken, SC

Dawn Kaback

Westinghouse Savannah River Co.

Aiken, SC

Lucy Knowles

U.S. Department of Energy

Aiken, SC

Linda K. McClain

U.S. Department of Energy

Aiken, SC

Elizabeth Rasor

NUS Corporation

Aiken, SC

Charles Sherman

Westinghouse Savannah River Co.

Aiken, SC

Wade $C$. Whitaker

U.S. Department of Energy

Aiken, SC

DOE Headquarters Interviews

Richard Dailey

EH-231

Lisa Feldt

EH-221

Jim Fiore

EM-42 
Don Fulmer

EM-42

Andrea Heintzelman

EH-25

Stanley Lichtman

EH-25

Ralph Lightner

EM-45

Sally Mann

EM-44

Kathleen Taimi

EH-22

Larry Weiner

EH-5

William Wisenbaker

EM-42 


\section{APPENDIX E}

LIST OF ISSUE GROUPS, SUPPORTING

INFORMATION, AND NEEDED ACTION ITEMS 


\section{APPENDIX E}

\section{LIST OF ISSUE GROUPS, SUPPORTING INFORMATION, AND NEEDED ACTION ITEMS}

The following table lists the 13 issue groups, issues with in each group, supporting information, and needed actions compiled from the conference calls and interviews with Field Office and DOE HQ personnel. This table was presented at the December workshop. 
ISSUE GROUP I: REGULATORY INTEGRATION

\begin{tabular}{|c|c|c|}
\hline ISSUES & SUPPORTING IMFORMATION & NEEDED ACTION ITEMS \\
\hline $\begin{array}{l}\text { RCRA/CERCLA FUNCTIONAL } \\
\text { EQUIVALENCY }\end{array}$ & $\begin{array}{l}\text { Competing regulatory agencies } \\
\text { (funds, schedules, priorities) } \\
\text { Competing activity requirements } \\
\text { Built into FFAs but execution } \\
\text { relatively untested } \\
\end{array}$ & $\begin{array}{l}\text { Compare Activity Requirements } \\
\text { Develop Guidance } \\
\text { Issue Example Document(s) }\end{array}$ \\
\hline NEPA/CERCLA INTEGRATION & $\begin{array}{l}\text { DOE wants both, EPA only CERCLA } \\
\text { CEQ wants both, DOJ wants } \\
\text { resolution } \\
\text { EPA expects no impacts (funds, } \\
\text { schedules) } \\
\text { Increased chance for suits under } \\
\text { NEPA }\end{array}$ & $\begin{array}{l}\text { Compare Activity Requirements } \\
\text { Develop Guidance } \\
\text { Issue Example Document(s) } \\
\text { Facilitate Coordination among } \\
\text { DOE, CEQ, DOJ,EPA }\end{array}$ \\
\hline $\begin{array}{l}\text { OTHER REGULATORY INTEGRATION } \\
\text { CONCERNS }\end{array}$ & $\begin{array}{l}\text { National Resource Damage } \\
\text { Assessment } \\
\text { Use of LDRs in Superfund cleanup } \\
\text { Use of RCRA as CERCLA ARAR } \\
\text { DBD coordination with CERCLA and } \\
\text { NCP }\end{array}$ & \\
\hline
\end{tabular}


ISSUE GROUP II: REGULATORY STREAMLINING

\begin{tabular}{|c|c|c|}
\hline ISSUES & SUPPORTING IMFORMATION & MEEDED ACTION ITEMS \\
\hline PERMITTING PROCESS & $\begin{array}{l}\text { Massive TSD infrastructure } \\
\text { buildup ahead } \\
\text { Permitting is multi-year process } \\
\text { Regulators limited by } \\
\text { qualifications of permit } \\
\text { reviewers } \\
\text { Regulators limited by volume of } \\
\text { permit applications }\end{array}$ & $\begin{array}{l}\text { Identify and communicate upcoming } \\
\text { bottlenecks } \\
\text { Develop streaml ining approaches } \\
\text { with regulators } \\
\text { Stress use of CERCLA on-site } \\
\text { exemptions }\end{array}$ \\
\hline $\begin{array}{l}\text { DOCUMENT REVIEW AND APPROVAL } \\
\text { TIMES }\end{array}$ & $\begin{array}{l}\text { Uncertain DOE review and approval } \\
\text { process } \\
\text { State and EPA delays } \\
\text { Lack of standardized formats } \\
\text { Coordination of reviews with EPA }\end{array}$ & $\begin{array}{l}\text { Identify key reports or report } \\
\text { categories } \\
\text { Establish standardized DOE review } \\
\text { and approval process/times } \\
\text { Develop tracking/priority system } \\
\text { Standardize document formats } \\
\text { whenever possible } \\
\text { Negotiate realistic review times }\end{array}$ \\
\hline
\end{tabular}




\section{ISSUE GROUP II: REGULATORY STREAMLINING (Cont'd)}

\begin{tabular}{|c|c|c|}
\hline ISSUES & SUPPORTING INFORMATION & MEEDED ACTION ITEMS \\
\hline EXTENT OF SITE CHARACTERIZATION & $\begin{array}{l}\text { Technology driven } \\
\text { characterization } \\
\text { Characterization has low decision } \\
\text { risk } \\
\text { DOE and regulators focus on } \\
\text { characterization } \\
\begin{array}{l}\text { Most FFAs focus on } \\
\text { characterization }\end{array}\end{array}$ & $\begin{array}{l}\text { Define characterization drivers } \\
\text { Refine data quality objectives } \\
\text { (DQOs) } \\
\text { Develop DQO and(observational } \\
\text { approach guidance }\end{array}$ \\
\hline TECHNOLOGY BASELINE & $\begin{array}{l}\text { Need to assess cleanup capability } \\
\text { of present technology } \\
\text { Need to project technology } \\
\text { requirements } \\
\text { How to anticipate treatability } \\
\text { data needs }\end{array}$ & $\begin{array}{l}\text { Define cleanup requirements } \\
\text { Define role/capability of present } \\
\text { technology } \\
\text { Assess technology development } \\
\text { needs }\end{array}$ \\
\hline LIMITEO OR EXPEOITEO CLEANUPS & $\begin{array}{l}\text { How to stabilize waste and } \\
\text { minimize its spread } \\
\text { Appropriate focus on cleanup } \\
\text { actions } \\
\text { How to measure cleanup progress } \\
\text { Limited success in Superfund }\end{array}$ & $\begin{array}{l}\text { Assess use and requirements } \\
\text { Develop guidance }\end{array}$ \\
\hline
\end{tabular}




\section{ISSUE GROUP II: REGULATORY STREAMLINING (Cont'd)}

\begin{tabular}{||c|c|c|}
\hline \multicolumn{1}{|c|}{ ISSUES } & SUPPORTING INFORMATION & \multicolumn{1}{c|}{ MEEDED ACTION ITEMS } \\
\hline NPL VERSUS NON-NPL SITE CLEANUPS & $\begin{array}{l}\text { DOE Order 5400.4 } \\
\text { Low regulatory priority for some } \\
\text { non-NPL sites }\end{array}$ & Redraft DoE Order 5400.4 \\
\hline
\end{tabular}


ISSUE GROUP III: CLEANUP AUTHORITY AND CONSISTENCY

\begin{tabular}{|l|l|l|}
\hline \multicolumn{1}{|c|}{ ISSUES } & \multicolumn{1}{|c|}{ SUPPORTING INFORMATION } & \multicolumn{1}{c|}{ NEEDED ACTION ITEMS } \\
\hline $\begin{array}{l}\text { CLEANUP OF SITES NOT UNDER DOE's } \\
\text { CONTROL }\end{array}$ & $\begin{array}{l}\text { Land privately owned } \\
\text { Access limitations } \\
\text { DOE legal responsibility } \\
\text { Community knowledge of sites } \\
\text { FUSRAP }\end{array}$ & $\begin{array}{l}\text { Assess private versus government } \\
\text { rights } \\
\text { Define DOE responsibility } \\
\text { Inform communities/owners }\end{array}$ \\
\hline STATE VERSUS FEDERAL AUTHDRITY & $\begin{array}{l}\text { Variable State cleanup and risk } \\
\text { reduction levels } \\
\text { DOE agreements (non-attainable } \\
\text { cleanup/risk reduction targets) } \\
\text { Uncertain State authority over } \\
\text { radioactive waste } \\
\text { Meeting State requirements for } \\
\text { requirements' sake } \\
\text { High characterization costs }\end{array}$ & $\begin{array}{l}\text { Work with EPA/States to develop } \\
\text { consistent/fleanup standards }\end{array}$ \\
\hline $\begin{array}{l}\text { DOE addressing RCRA/CERCLA/NEPA } \\
\text { Is characterization more } \\
\text { stringent for DOE? } \\
\text { Are cleanup levels more } \\
\text { restrictive for DOE? }\end{array}$ & $\begin{array}{l}\text { Perform comparison of federal } \\
\text { versus private cleanup agreements }\end{array}$ & \\
\hline PRIVATE INDUSTRY DOE VERSUS & & \\
\hline
\end{tabular}


ISSUE GROUP III: CLEANUP AUTHORITY AND CONSISTENCY (Cont'd)

\begin{tabular}{||l|l|l|}
\hline \multicolumn{1}{|c|}{ ISSUES } & \multicolumn{1}{|c|}{ SUPPORTING INFORMATION } & \multicolumn{1}{|c|}{ NEEDED ACTION ITEMS } \\
\hline $\begin{array}{l}\text { CONSISTENCY AMONG EPA REGIONS AND } \\
\text { STATES }\end{array}$ & $\begin{array}{l}\text { Inconsistencies limit DOE } \\
\text { knowledge transfer between sites } \\
\text { Essentially dealing with multiple } \\
\text { regulators/regulations } \\
\text { Limits effectiveness of } \\
\text { centralized DOE-HQ control }\end{array}$ & $\begin{array}{l}\text { EPA develop centralized guidance } \\
\text { cleanup approaches } \\
\text { DOE develop consistent cleanup } \\
\text { approaches } \\
\text { DoE/States/EPA develop regional } \\
\text { cleanup approaches } \\
\text { Develop common decision } \\
\text { tools/information systems }\end{array}$ \\
\hline
\end{tabular}


ISSUE GROUP IV: ENVIRONMENTAL MANAGEMENT INTEGRATION (WO and ER)

\begin{tabular}{|c|c|c|}
\hline ISSUES & SUPPORTING INFORMATION & NEEDED ACTION ITEMS \\
\hline $\begin{array}{l}\text { TSD OF WASTE GENERATED FROM ER } \\
\text { ACTIVITIES }\end{array}$ & $\begin{array}{l}\text { Uncertain roles during } \\
\text { characterization } \\
\text { Uncertain roles during cleanup } \\
\text { Uncertain interim roles as TSDs } \\
\text { built } \\
\text { Need to define roles at ER Site } \\
\text { versus WO/ER Site } \\
\text { Uncertain TSD permitting status } \\
\text { and requirements } \\
\text { Resource allocations for TSOs } \\
\text { versus site cleanups }\end{array}$ & $\begin{array}{l}\text { Define present and interim WO and } \\
\text { ER roles } \\
\text { Define permitting strategies } \\
\text { Develop basis for funding } \\
\text { allocations (facilities versus } \\
\text { cleanup) } \\
\text { ER must provide better waste } \\
\text { generation estimates to WO }\end{array}$ \\
\hline WASTE MINIMIZATION & $\begin{array}{l}\text { Waste generation versus waste } \\
\text { minimization } \\
\text { Huge volumes of low-level waste } \\
\text { Limited end-use (e.g. recycling) } \\
\text { discussions } \\
\text { Economic value of separated } \\
\text { materials }\end{array}$ & $\begin{array}{l}\text { Factor recycling into cleanup } \\
\text { strategy } \\
\text { Survey/communicate inventory of } \\
\text { strategic materials } \\
\text { Assess value of recovered or } \\
\text { recoverable materials }\end{array}$ \\
\hline
\end{tabular}


ISSUE GROUP IV: ENVIRONMENTAL MANAGEMENT INTEGRATION (Cont'd)

\begin{tabular}{|l|l|l|}
\hline \multicolumn{1}{|c|}{ ISSUES } & \multicolumn{1}{|c|}{ SUPPORTING INFORMATION } & \multicolumn{1}{|c|}{ MEEDED ACTION ITENS } \\
\hline WASTE TRANSPORTATION & $\begin{array}{l}\text { Waste transport key to many site } \\
\text { cleanups }\end{array}$ & $\begin{array}{l}\text { Define role of sample/waste } \\
\text { transport in cleanup strategy } \\
\text { Interstate } \\
\text { Intra-site }\end{array}$ \\
\hline
\end{tabular}


ISSUE GROUP V: IMPLEMENTATION OF AGREEMENTS/DOCUMENTATION

\begin{tabular}{|l|l|l|}
\hline \multicolumn{1}{|c|}{ ISSUES } & \multicolumn{1}{|c|}{ SUPPORTING IMFORMATION } & \multicolumn{1}{|c|}{ MEEDED ACIION ITEMS } \\
\hline $\begin{array}{l}\text { PROGRAMMATIC ENVIRONMENTAL IMPACT } \\
\text { STATEMENT }\end{array}$ & $\begin{array}{l}\text { Timel iness/integrated role of } \\
\text { NEPA reports } \\
\text { Concern over redoing interim } \\
\text { actions } \\
\text { Involve total systems approach } \\
\text { (exhuming to disposal) } \\
\text { Viewed as establishing key DOE } \\
\text { cleanup strategy } \\
\text { Inadequate emphasis on PEIS } \\
\text { Some States may not be willing to } \\
\text { sign permits without PEIS }\end{array}$ & $\begin{array}{l}\text { Define integrated roles of PEIS, } \\
\text { Site EISs, and site NEPA } \\
\text { documents } \\
\text { Assess schedul ing impacts from } \\
\text { dependent roles }\end{array}$ \\
$\begin{array}{l}\text { Report routine PEIS status } \\
\text { Communicate issues, schedules, } \\
\text { management, etc. }\end{array}$ & \\
\hline
\end{tabular}


ISSUE GROUP V: IMPLEMENTATION OF AGREEMENTS/DOCUMENTATION (Cont'd)

\begin{tabular}{|c|c|c|}
\hline ISSUES & SUPPORTING INFORMATION & MEEDED ACTION ITEMS \\
\hline $\begin{array}{l}\text { FEDERAL FACILITY AND INTERAGENCY } \\
\text { AGREEMENTS (FFAs/IAGS) }\end{array}$ & $\begin{array}{l}\text { Agreements individually developed } \\
\text { Collective commitments unknown, } \\
\text { need to track } \\
\text { Division/level of commitment } \\
\text { tracking unknown } \\
\text { Agreements as sume funds and } \\
\text { technologies will exist } \\
\text { Need to build in flexibility } \\
-\quad \text { Milestones } \\
-\quad \text { Dollars } \\
\text { Inconsistency between agreements } \\
\text { Activity transition between } \\
\text { agreements } \\
\text { How is cleanup success measured? } \\
\text { Renegotiation }\end{array}$ & $\begin{array}{l}\text { Assess DOE;s total commitments } \\
\text { Define tracking needs and } \\
\text { responsibilities } \\
\text { Establish lead management } \\
\text { organization } \\
\text { Develop transition guidance } \\
\text { (pre/post agreement) } \\
\text { Develop measurement of agreement } \\
\text { success }\end{array}$ \\
\hline
\end{tabular}


ISSUE GROUP V: IMPLEMENTATION OF AGREEMENTS/DOCUMENTATION (Cont'd)

\begin{tabular}{|l|l|l|}
\hline \multicolumn{1}{|c|}{ ISSUES } & \multicolumn{1}{|c|}{ SUPPORTING INFORMATION } & \multicolumn{1}{c|}{ NEEDED ACTION ITEMS } \\
\hline INTERAGENCY RELATIONS & $\begin{array}{l}\text { Need to pool common tools, } \\
\text { experiences, and knowledge }\end{array}$ & $\begin{array}{l}\text { Develop interagency (DOE, DOD, } \\
\text { DOT) working groups }\end{array}$ \\
& $\begin{array}{l}\text { Application of OSHA requirements } \\
\text { to D\&D facilities }\end{array}$ & $\begin{array}{l}\text { Assess OSHA applicability to 08D } \\
\text { facilities } \\
\text { No common decision tools, } \\
\text { databases }\end{array}$ \\
\hline
\end{tabular}

$\underset{n}{m}$ 


\section{ISSUE GROUP VI: EPA ISSUES}

\begin{tabular}{|c|c|c|}
\hline ISSUES & SUPPORTING INFORMATION & NEEDED ACTION ITEMS \\
\hline ENVIRONMENTAL POLICY & $\begin{array}{l}\text { Fragmented environmental policies } \\
\text { Lack of inter-office coordination } \\
\text { Limited understanding of DOE's } \\
\text { issues } \\
\text { Limited experience with rad or } \\
\text { mixed waste. }\end{array}$ & $\begin{array}{l}\text { Work with EPA on coordinated } \\
\text { environmental policy } \\
\text { Communicate DOE's environmental } \\
\text { issues }\end{array}$ \\
\hline STAFF & $\begin{array}{l}\text { Lack of experienced staff } \\
\text { Limited staff numbers } \\
\text { Lack of technical/managerial } \\
\text { counterparts with DOE } \\
\text { Staff turnaround }\end{array}$ & $\begin{array}{l}\text { Support EPA in increasing staff } \\
\text { committed to DOE } \\
\text { Emphasize need to commit } \\
\text { experienced staff } \\
\text { Support EPA in developing DOE } \\
\text { counterparts }\end{array}$ \\
\hline $\begin{array}{l}\text { REGIONAL AUTONOMY AND } \\
\text { INCONSISTENCY }\end{array}$ & $\begin{array}{l}\text { Inconsistent cleanup } \\
\text { approaches/requirements } \\
\text { Reworking documents } \\
\text { Inconsistent contractor reviews } \\
\text { of reports } \\
\text { Need consistent EPA guidance }\end{array}$ & $\begin{array}{l}\text { Develop common decision } \\
\text { tools/data bases }\end{array}$ \\
\hline
\end{tabular}


ISSUES GROUP VII: GENERAL DOE GUIDANCE AND ADMINISTRATION

\begin{tabular}{|c|c|c|}
\hline ISSUES & SUPPORTING INFORMATION & NEEDED ACTION ITEMS \\
\hline $\begin{array}{l}\text { DELEGATION OF AUTHORITY AND } \\
\text { RESPONSIBILIIY }\end{array}$ & $\begin{array}{l}\text { HQ Micromanagement } \\
\text { Confusing division of DOE } \\
\text { authority and responsibility } \\
\text { HQ develop guidance and } \\
\text { performance goals } \\
\text { F0s responsible for following } \\
\text { guidance and meeting goals } \\
\text { Delegate authority to fOs to } \\
\text { maximum extent possible } \\
\text { - Categorical exclusions for } \\
\text { NEPA/document approval } \\
\text { Centralization of decisions and } \\
\text { streamlining are mutually } \\
\text { inconsistent approaches } \\
\text { Popular versus technically } \\
\text { defensible decisions } \\
\text { - Appointed DOE officials } \\
\text { (Schedule C) often lack } \\
\text { technical perspective }\end{array}$ & $\begin{array}{l}\text { Clarify } \mathrm{HQ} \text { and } \mathrm{FO} \\
\text { authority/responsibility }\end{array}$ \\
\hline
\end{tabular}


ISSUE GROUP VII: GENERAL DOE GUIDANCE AND ADMINISTRATION (Cont'd)

\begin{tabular}{|c|c|c|}
\hline ISSUES & SUPPORTING INFORMATION & MEEDED ACTION IJEMS \\
\hline ADMINISTRATIVE REQUESTS & $\begin{array}{l}\text { Poorly coordinated and redundant } \\
\text { requests/requirements } \\
-\quad \text { Issue exercises } \\
\text { Tiger Jeams, budget } \\
\text { requests, guidance reviews, } \\
\text { ADSs } \\
\text { Roadmaps } \\
\text { Massive Fo/subcontractor resource } \\
\text { drain } \\
\text { Little value added } \\
\text { Lack of ER and EH coordination } \\
\text { and communication } \\
\text { - Need single contact on } \\
\text { FFAs, IAG, LDRs, NEPA, etc. } \\
\text { Lack of timely response to } \\
\text { information requests from FO }\end{array}$ & $\begin{array}{l}\text { Develop and follow guidance for } \\
\text { requests } \\
\text { Maintain single, informed contact } \\
\text { for requests } \\
\text { Assess the impact of requests on } \\
\text { staff and morale }\end{array}$ \\
\hline
\end{tabular}


ISSUE GROUP VII: GENERAL DOE GUIDANCE AND ADMINISTRATION (Cont'd)

\begin{tabular}{|c|c|c|}
\hline ISSUES & SUPPORTING INFORMATION & NEEDED ACTION ITEMS \\
\hline BUDGET AND FUNDING & $\begin{array}{l}\text { Inability to financially comply } \\
\text { with regulations/agreements } \\
\text { Unobligated contingency funds } \\
\text { (budget for unknowns) } \\
\text { Planning for FY94 when FY92 needs } \\
\text { unknown } \\
\text { Liability concerns contribute to } \\
\text { budget shortfall } \\
\text { OMB restrictions } \\
\text { Compliance requires long-term } \\
\text { budget commitments } \\
\text { Limited resources always reality } \\
\text { No quid pro quo with Congress }\end{array}$ & $\begin{array}{l}\text { Develop decision basis for budget } \\
\text { allocations } \\
\text { Build closer tie between } \\
\text { Agreements and budget }\end{array}$ \\
\hline CLEANUP SUBCONTRACTORS & $\begin{array}{l}\text { Little word on } 5400.4 \text { conflict of } \\
\text { interest provision } \\
\text { New contracting schedule will } \\
\text { require "growing pains" } \\
\text { Local and EPA acceptance of } \\
\text { regional contractors questioned }\end{array}$ & $\begin{array}{l}\text { Clarify status and intent of } \\
5400.4\end{array}$ \\
\hline
\end{tabular}


ISSUE GROUP VII: GENERAL DOE GUIDANCE AND ADMINISTRATION (Cont'd)

\begin{tabular}{|c|c|c|}
\hline ISSUES & SUPPORTING INFORMATION & NEEDED ACTION ITEMS \\
\hline $\begin{array}{l}\text { LIABILITY PROTECTION FOR STAFF } \\
\text { AND CONTRACTORS }\end{array}$ & $\begin{array}{l}\text { Compliance with State laws rather } \\
\text { than } H Q \text { guidance } \\
\text { Lack of indemnification for } \\
\text { actions over which one has no } \\
\text { control } \\
\text { Contributes to unrestrained } \\
\text { budget requests }\end{array}$ & $\begin{array}{l}\text { Develop liability and } \\
\text { indemnification policies }\end{array}$ \\
\hline $\begin{array}{l}\text { USE OF EXISTING ENVIRONMENTAL } \\
\text { DATA }\end{array}$ & $\begin{array}{l}\text { Acceptance of existing data } \\
\text { Declassification of existing data }\end{array}$ & $\begin{array}{l}\text { Assess use of existing data } \\
\text { Define data classification/declas } \\
\text { sification needs }\end{array}$ \\
\hline $\begin{array}{l}\text { QUALITY ASSURANCE/QUALITY CONTROL } \\
\text { STANDARDS }\end{array}$ & $\begin{array}{l}\text { NQA-1 standards do not function } \\
\text { Need to coordinate standards with } \\
\text { EPA } \\
\text { Need reasonable analytical data } \\
\text { quality approach } \\
\text { Impacts spectrum of data } \\
\text { collection - - more than } \\
\text { characterization } \\
\text { State/EPA certification of labs }\end{array}$ & $\begin{array}{l}\text { Develop QA/QC guidance for } \\
\text { data/tools/technologies } \\
\text { Correlate cleanup decisions with } \\
\text { data quality needs } \\
\text { Clarify use of CLP protocols } \\
\text { Develop policy on analytical need } \\
\text { hierarchy }\end{array}$ \\
\hline
\end{tabular}


ISSUE GROUP VII: GENERAL DOE GUIDANCE AND ADMINISTRATION (Cont'd)

\begin{tabular}{||c|l|l|}
\hline \multicolumn{1}{|c|}{ ISSUES } & \multicolumn{1}{|c|}{ SUPPORTING INFORMATION } & \multicolumn{1}{|c|}{ NEEOED ACTION ITEMS } \\
\hline PROTRACTED PROCUREMENT CYCLE & $\begin{array}{l}\text { Existing procurement cycle is } \\
\text { long } \\
\text { Cleanup actions require extended } \\
\text { contractual commitments }\end{array}$ & $\begin{array}{l}\text { Develop mechanism for testing } \\
\text { new/innovative technologies } \\
\text { Assess streamlined procurement } \\
\text { approaches }\end{array}$ \\
\hline
\end{tabular}


ISSUE GROUP VIII: RISK MANAGEMENT

\begin{tabular}{|c|c|c|}
\hline ISSUES & SUPPORTING INFORMATION & NEEDED ACTION ITEMS \\
\hline $\begin{array}{l}\text { SYSTEMS APPROACH TO ENVIRONMENTAL } \\
\text { MANAGEMENT }\end{array}$ & $\begin{array}{l}\text { Decision framework for } \\
\text { comparing/minimizing risks } \\
\text { Economic, political, technical, } \\
\text { schedule, health, etc. tradeoffs } \\
\text { Need acceptance (public, decision } \\
\text { makers) of risk tradeoffs } \\
\text { Concerns over worker/public } \\
\text { exposure during cleanup } \\
\text { Concerns over true risk } \\
\text { reductions from cleanups } \\
\text { Natural system controls } \\
\text { Technology limitations } \\
\text { Need broad based input } \\
\text { Need tools }\end{array}$ & $\begin{array}{l}\text { Develop risk management approach } \\
\text { to decision making }\end{array}$ \\
\hline
\end{tabular}




\section{ISSUE GROUP IX: FUTURE LAND USE}

\begin{tabular}{|l|l|l|}
\hline \multicolumn{1}{|c|}{ ISSUES } & \multicolumn{1}{|c|}{ SUPPORTING INFORMATION } & \multicolumn{1}{|c|}{ MEEDED ACTION ITEMS } \\
\hline FUTURE LAND USE & $\begin{array}{l}\text { Key to defining cleanup } \\
\text { approaches/levels }\end{array}$ & Develop land use policy \\
& $\begin{array}{l}\text { Policy integrated into PEIS } \\
\text { National/regional/State natural } \\
\text { resources } \\
\text { Waste storage/disposal areas } \\
\text { needed } \\
\text { Institutional controls may exist }\end{array}$ & \\
\hline
\end{tabular}


ISSUE GROUP X: CLEANUP LEVELS

\begin{tabular}{|c|c|c|}
\hline ISSUES & SUPPORTING INFORMATION & NEEDED ACTION ITEMS \\
\hline LIMITED CLEANUP STANDARDS & $\begin{array}{l}\text { No soil cleanup standards } \\
\text { Isotope-specific standards } \\
\text { missing (soil, groundwater) } \\
\text { Cleanup levels for D\&D facilities } \\
\text { Tied to land use }\end{array}$ & Work with EPA and ATSDR \\
\hline BASIS FOR CLEANUP LEVELS & $\begin{array}{l}\text { Technology driven } \\
\text { Regulation driven } \\
\text { Health/risk driven } \\
\text { How to measure/judge cleanup } \\
\text { success }\end{array}$ & $\begin{array}{l}\text { Clarify basis for cleanup levels } \\
\text { Assess attainability of cleanup } \\
\text { levels } \\
\text { Asses risk-driven benefits }\end{array}$ \\
\hline $\begin{array}{l}\text { FLEXIBILITY OF REMEDIAL ACTION } \\
\text { CLEANUPS }\end{array}$ & $\begin{array}{l}\text { Following prescribed cleanup } \\
\text { levels--conservative approach } \\
\text { De minimis contaminant levels } \\
\text { Cleanups based on letter of law } \\
\text { rather than on risk }\end{array}$ & Promote risk-driven cleanups \\
\hline COMMON TERMINOLOGY REQUIREMENTS & $\begin{array}{l}\text { Definitions: Pristine; } \\
\text { Background; BDAT; Below } \\
\text { Regulatory Concern }\end{array}$ & $\begin{array}{l}\text { Agree on common terminology with } \\
\text { regulators } \\
\text { Factor into Agreements }\end{array}$ \\
\hline
\end{tabular}




\section{ISSUE GROUP XI: DOE INFRASTRUCTURE}

\begin{tabular}{|c|c|c|}
\hline ISSUES & SUPPORTING INFORMATION & MEEDED ACTION ITEMS \\
\hline DOE INFRASTRUCTURE & $\begin{array}{l}\text { Staff } \\
\text { Subcontractors } \\
\text { TSD Facilities } \\
\text { Laboratories } \\
\text { Funding levels } \\
\text { Master plan guiding strategic } \\
\text { planning } \\
\text { Decision aiding tools and data } \\
\text { bases }\end{array}$ & \\
\hline
\end{tabular}


ISSUE GROUP XII: INFORMATION SYSTEMS

\begin{tabular}{|l|l|l|}
\hline \multicolumn{1}{|c|}{ ISSUES } & \multicolumn{1}{|c|}{ SUPPORTING INFORMATION } & \multicolumn{1}{c|}{ NEEDED ACTION ITEMS } \\
\hline INFORMATION SYSTEMS & $\begin{array}{l}\text { Access (internal and external) to } \\
\text { data } \\
\text { Traceable linkage from collection } \\
\text { to use } \\
\text { Electronic systems } \\
\text { Preserve knowledge base } \\
\text { generation } \\
\text { Define access/storage/retrieval } \\
\text { needs } \\
\text { Develop guidance } \\
\text { Common linkage across DoE } \\
\text { Motivation to share information } \\
\text { required } \\
\text { Characterization, technology, and } \\
\text { treatability data }\end{array}$ \\
\hline
\end{tabular}




\section{ISSUE GROUP XIII: COMMUNITY RELATIONS PROGRAM}

\begin{tabular}{|l|l|l|}
\hline \multicolumn{1}{|c|}{ ISSUES } & \multicolumn{1}{|c|}{ SUPPORTING IMFORMATION } & \multicolumn{1}{c|}{ NEEDED ACTION ITEMS } \\
\hline COMMUNITY RELATIONS PROGRAM & $\begin{array}{l}\text { Organizational visibility } \\
\text { Program reviews } \\
\text { Guidance }\end{array}$ & $\begin{array}{l}\text { Develop accountable organization } \\
\text { Issue guidance }\end{array}$ \\
\hline
\end{tabular}


APPENDIX $F$

WORKSHOP INFORMATION PACKET 


\section{APPENDIX $F$}

\section{WORKSHOP INFORMATION PACKET}

The following information was sent to workshop attendees to prepare them for what would occur at the December workshop and give them the chance to review the issues compiled from the conference calls and interviews. 


\section{Department of Energy \\ Washington, DC 20585}

NOV 301990

\section{Distribution}

My memorandum of 0ctober 3, 1990, announced a two-part exercise as a first step in an ongoing process to identify, track, and resolve regulatory and institutional issues that are impeding the environmental cleanup process across the Department of Energy (DOE) complex. Pacific Northwest Laboratory (PNL), the exercise coordinator, has completed the first part of the exercise, a series of conference calls and meetings with DOE Field Office and Headquarters staff. I would like to thank all the participants of the calls and meetings for their responsiveness and input. Your responses have been consolidated and condensed into issue groups, issues, comments, and some suggested support activities (Attachment I). This information will serve to initiate discussions during the follow-up workshop to be held at the Holiday Inn in Gaithersburg, Maryland, on December 17 and 18 (NoTE DATE CHANGE). You have been nominated to represent your office or organization at this meeting. Attachments 2 and 3 address the workshop agenda and general logistics information.

Not surprisingly, many of the identified issues have already been cited in the Five-Year Plan or other documents. However, issue identification is but the first step. What remains to be done is to implement a process to prioritize, track, and resolve the issues. The December workshop will focus on this process.

In preparation for the workshop, please review Attachment 1 and begin to formulate ideas on tasks, processes, or mechanisms that could be implemented by Field Office and/or Headquarters staff to address these issues. Also, as you formulate your ideas, please put a premium on Complex-wide applicability. The greatest benefit from this workshop will lie in the identification of steps towards the solution of common problems being faced across the complex.

We all realize that none of the issues confronting us can be resolved in a 2-day meeting. Rather, the process I envision will require a coordinated, sustained effort by DOE staff from across the Complex. I believe that the perspectives, experience, and expertise of the workshop participants will serve as catalysts to initiate this process. 
I look forward to meeting you in December and working with you and your staff on this exercise. If you have any questions, please contact william (Bi11) Falion at 202/646-7787.

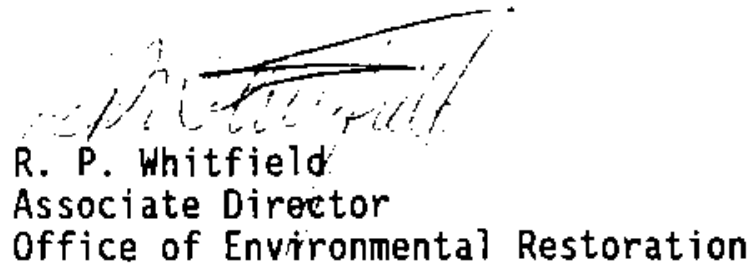

3 Attachments: Consolidated List of Issues

Workshop Agenda

Logistics Information 


\section{Distribution:}

T. Buqo, Nevada Operations office

P. Davis, Sandia National Laboratories

S. Davis, Brookhaven National Laboratory

o. Earle, Westinghouse Idaho Nuclear Company

B. Grandfield, Dayton Area office

I. Hall, EG\&G Idaho, Inc.

F. Hoffman, Livermore National Laboratory

D. Ingle, Pinellas Area Office

P. Keary, Kansas City Area Office

J. Keller, Pacific Northwest Laboratory

A. Kleinrath, Dayton Area office

R. Landon, Westinghouse Hanford Company

J. Miller, Martin Marietta Energy systems, Inc.

B. Quinn, Pacific Northwest Laboratory

P. Schumann, Los Alamos Area office

C. Sherman, Westinghouse Savannah River Company 
ATTACHMTENT 1

\section{CONSOLIDATED GROUPING OF ISSUES CITED \\ DURING FIELD OFFICE CONFERENCE CALLS AND HEADQUARTERS MEETINGS}

\section{INTRODUCTION}

During October and November 1990, PNL coordinated a series of conference calls and meetings with DOE Field office and Headquarters staff. The purpose of these discussions was to begin to identify those regulatory and institutional issues that are posing the greatest impediments to environmental restoration progress for DOE.

This document is a condensed compilation of the issues that were identified and organized into 13 major groups (I-XIII). Within each major group, $1-8$ specific issues are listed, along with bulleted comments, observations or needs that were also cited during the calls and meetings. Finally, some specific support activities are indicated whose implementation would be appropriate first steps towards the ultimate resolution of the described issue.

At the upcoming December workshop, participants will have two main tasks:

To further develop the list of issues and collectively choose about five key issue groups to focus on at the workshop; and

- To work independently in small, issue-specific groups to refine, expand or augment the suggested support activities by identifying tasks, processes and mechanisms that could be implemented.

Ideas developed by each group will be presented for discussion in a plenary session for further enhancement and to take advantage of the group's collective insight, perspective, and experience.

During the workshop, participants will select and focus on $f i v e$ or six major issue groups. However, it should be emphasized that all of the issues cited during the conference calls and meetings have been transmitted to DOE Headquarters (ER) for review and consideration. 
I. REGULATORY INTEGRATION

1. RCRA/CERCLA FUNCTIONAL EQUIVALENCY

- Competing regulatory agencies (funds, schedules, priorities)

- Competing activity requirements

- Built into FFAs but execution relatively untested

Support Activities:

A. Compare Activity Requirements

B. Develop Guidance

C. Issue Example Document(s)

2. NEPA/CERCLA INTEGRATION

- DOE wants both, EPA only CERCLA

- CEQ wants both, DOJ wants resolution

- EPA expects no impacts (funds, schedules)

- Increased chance for suits under NEPA

Support Activities:

A. Compare Activity Requirements

B. Develop Guidance

C. Issue Example Document(s)

D. Facilitate Coordination among DOE, CEQ, DOJ, EPA

3. OTHER REGULATORY INTEGRATION CONCERNS

- National Resource Damage Assessment

- Use of LDRs in superfund cleanup

- Use of RCRA as CERCLA ARAR

- D\&D coordination with CERCLA and NCP

II. REGULATORY STREAKIINING

1. PERMITTING PROCESS

- Massive TSD infrastructure buildup ahead

- Permitting is multi-year process

- Regulators linited by qualifications of permit reviewers

- Regulators limited by volume of permit applications

Support Activities:

A. Identify and communicate upcoring bottlenecks

B. Develop streamlining approaches with regulators

C. Stress use of CERCLA on-site exemptions 
2. DOCUMENT REVIEW AND APPROVAL TIMES

- Uncertain DOE review and approval process

- State and EPA delays

- Lack of standardized formats

- Coordination of reviews with EPA

Support Activities:

A. Identify key reports or report categories

B. Establish standardized DOE review and approval process/times

C. Develop tracking/priority system

D. Standardize document formats whenever possible

E. Negotiate realistic review times

3. EXTENT OF SITE CHARACTERIZATION

- Technology driven characterization

- Characterization has low decision risk

- DOE and regulators focus on characterization

- Most FFAs focus on characterization

Support Activities:

A. Define characterization drivers

B. Refine data quality objectives (DQOs)

C. Develop $D Q O$ and observational approach guidance

4. TECHNOLOGY BASELINE

- Need to assess cleanup capability of present technology

- Need to project technology requirements

- How to anticipate treatability data needs

Support Activities:

A. Define cleanup requirements

B. Define role/capability of present technology

C. Assess technology development needs

5. LIMITED OR EXPEDITED CLEANUPS

- How to stabilize waste and minimize its spread

- Appropriate focus on cleanup actions

- How to measure cleanup progress

- Limited success in Superfund 
Support Activities:
A. Assess use and requirements
B. Develop guidance

6. NPL VERSUS NON-NPL SITE CLEANUPS
- DOE Order 5400.4
- Low regulatory priority for some non-NPL sites
Support Activities:
A. Define cleanup priorities
B. Redraft DOE Order 5400.4

\section{CLEANUP AUTHORITY AND CONSISTENCY}

1. CLEANUP OF SITES NOT UNDER DOE'S CONTROL
- Land privately owned
- Access limitations
- DOE legal responsibility
- Community knowledge of sites
- FUSRAP

Support Activities:
A. Assess private versus government rights
B. Define DOE responsibility
C. Inform communities/owners

2. STATE VERSUS FEDERAL AUTHORITY

- Variable state cleanup and risk reduction levels

- DOE agreements (non-attainable cleanup/risk reduction targets)

- Uncertain state authority over radioactive waste

- Meeting state requirements for requirements' sake

- High characterization costs

Support Activities:

A. Work with EPA/States to develop consistent/flexible national cleanup standards

3. REQUIREMENTS FOR DOE VERSUS PRIVATE INDUSTRY

- DOE addressing RCRA/CERCLA/NEPA

- Is characterization more stringent for DOE?

- Are cleanup levels more restrictive for DOE? 
Support Activities:

A. Perform comparison of federal versus private cleanup agreements

4. CONSISTENCY AMONG EPA REGIONS AND STATES

- Inconsistencies limit DOE knowledge transfer between sites

- Essentially dealing with multiple regulators/regulations

- Limits effectiveness of centralized DOE-HQ control

Support Activities:

A. EPA develop centralized guidance

B. EPA and DOE work toward joint cleanup approaches

C. DOE develop consistent cleanup approaches

D. DOE/States/EPA develop regional cleanup approaches

E. Develop common decision tools/information systems

IV. ENVIRONIENTAL MANAGEMENT INTEGRATION (WO and ER)

1. TSD OF WASTE GENERATED FROM ER ACTIVITIES

- Uncertain roles during characterization

- Uncertain roles during cleanup

- Uncertain interim roles as TSDs built

- Need to define roles at ER Site versus WO/ER site

- Uncertain TSD permitting status and requirements

- Resource allocations for TSDs versus site cleanups

Support Activities:

A. Define present and interim wo and ER roles

B. Define permitting strategies

C. Develop basis for funding allocations (facilities versus cleanup)

D. ER must provide better waste generation estimates to WO

\section{WASTE MINIMIZATION}

- Waste generation versus waste minimization

- Huge volumes of low-level waste

- Limited end-use (e.g. recycling) discussions

- Economic value of separated materials 
Support Activities:

A. Factor recycling into cleanup strategy
B. Survey/communicate inventory of strategic
c. materials

3. WASTE TRANSPORTATION

- Waste transport key to many site cleanups

- Interstate transport restrictions

- classification of transported waste

- Role of LDRs on waste movement/disposal outside areas of contamination

Support Activities:

A. Define role of sample/waste transport in cleanup strategy -Interstate -Intra-site

V. IMPLEMENTATION OF AGREEMENTS/DOCUMENTATION

1. PROGRAMMATIC ENVIRONMENTAL IMPACT STATEMENT

- Timeliness/integrated role of NEPA reports

- Concern over redoing interim actions

- Involve total systems approach (exhuming to disposal)

- Viewed as establishing key DOE cleanup strategy

- Inadequate emphasis on PEIS

- Some states may not be willing to sign permits without PEIS

Support Activities:

A. Define integrated roles of PEIS, Site EISs, and site NEPA documents

B. Assess scheduling impacts from dependent roles

C. Report routine PEIS status

D. Communicate issues, schedules, management, etc.

2. FEDERAL FACILITY AND INTERAGENCY AGREEMENTS (FFAS/IAGS)

- Agreements individually developed

- Collective commitments unknown, need to track

- Division/level of commitment tracking unknown

- Agreements assume funds and technologies will exist 
- Need to build in flexibility

-Milestones

-Dollars

-Schedules

- Inconsistency between agreements

- Activity transition between agreements

- How is cleanup success measured?

- Renegotiation

Support Activities:
A. Assess DOE;s total commitments
B. Define tracking needs and responsibilities
c. Establish lead management organization
D. Develop transition guidance (pre/post agreement)
E. Develop measurement of agreement success

3. INTERAGENCY RELATIONS

- Need to pool common tools, experiences, and knowledge

- Application of OSHA requirements to D\&D facilities

- No common decision tools, databases

Support Activities:
A. Develop interagency (DOE, DOD, DOT) working groups
B. Assess osHA applicability to D\&D facilities
c. Develop/link decision tools with EPA

VI. EPA ISSUES

1. ENVIRONMENTAL POLICY

- Fragmented environmental policies

- Lack of inter-office coordination

- Limited understanding of DOE's issues

- Limited experience with rad or mixed waste

Support Activities:

A. Work with EPA on coordinated environmental policy

B. Communicate DOE's environmental issues 
2. STAFF

- Lack of experienced staff

- Limited staff numbers

- Lack of technical/managerial counterparts with DOE

- Staff turnaround

Support Activities:
A. Support EPA in increasing staff committed to DOE
B. Emphasize need to commit experienced staff
c. Support EPA in developing DOE counterparts

3. REGIONAL AUTONOMY AND INCONSISTENCY

- Inconsistent cleanup approaches/requirements

- Reworking documents

- Inconsistent contractor reviews of reports

- Need consistent EPA guidance

Support Activities:

A. Develop common decision tools/data bases

VII. GENERAL DOE GUIDANCE AND ADMINISTRATION

1. DELEGATION OF AUTHORITY AND RESPONSIBILITY

- HQ Micromanagement

- Confusing division of DOE authority and responsibility

- HQ develop guidance and performance goals

- FOs responsible for following guidance and meeting goals

- Delegate authority to Fos to maximum extent possible

- Categorical exclusions for NEPA/document approval

- Centralization of decisions and streamlining are mutually inconsistent approaches

- Popular versus technically defensible decisions -Appointed DOE officials (Schedule C) often lack technical perspective

Support Activities:

A. Clarify $\mathrm{HQ}$ and $\mathrm{FO}$

authority/responsibility 
2. ADMINISTRATIVE REQUESTS

- Poorly coordinated and redundant requests/requirements

-Issue exercises

-Tiger Teams, budget requests, guidance reviews, ADSs

-Roadmaps

- Massive Fo/subcontractor resource drain

- Little value added

- Lack of ER and EH coordination and communication

- Need single contact on FFAs, IAG, LDRs, NEPA, etc

- Lack of timely response to information requests from FO

Support Activities:

A. Develop and follow guidance for requests

B. Maintain single, informed contact for requests

c. Assess the impact of requests on staff and morale

3. BUDGET AND FUNDING

- Inability to financially comply with regulations/agreements

- Unobligated contingency funds (budget for unknowns)

- Planning for FY94 when FY92 needs unknown

- Liability concerns contribute to budget shortfall

- OMB restrictions

- Compliance requires long-term budget commitments

- Limited resources always reality

- No quid pro quo with Congress

Support Activities:

A. Develop decision basis for budget

B. Build closer tie between Agreements and budget

4. CLEANUP SUBCONTRACTORS

- Little word on 5400.4 conflict of interest provision

- New contracting schedule will require "growing pains"

- Local and EPA acceptance of regional contractors questioned 
Support Activities:

A. Clarify status and intent of 5400.4

5. LIABILITY PROTECTION FOR STAFF AND CONTRACTORS

- Compliance with State laws rather than Ho guidance

- Lack of indemnification for actions over which one has no control

- Contributes to unrestrained budget requests

Support Activities:

A. Develop liability and indemnification policies

6. USE OF EXISTING ENVIRONMENTAL DATA

- Acceptance of existing data

- Declassification of existing data

Support Activities:
A. Assess use of existing data
B. Define data
classification/declassification needs

7. QUALITY ASSURANCE/QUALITY CONTROL STANDARDS

- NQA-1 standards do not function

- Need to coordinate standards with EPA

- Need reasonable analytical data quality approach

- Impacts spectrum of data collection-more than characterization

- State/EPA certification of labs

Support Activities:
A. Develop QA/QC guidance for data/tools/technologies
B. Correlate cleanup decisions with data quality needs
C. Clarify use of CLP protocols
D. Develop policy on analytical need hierarchy

\section{PROTRACTED PROCUREMENT CYCLE}

- Existing procurement cycle is long

- Cleanup actions require extended contractual commitments 
Support Activities:
A. Develop mechanism for testing new/innovative technologies
B. Assess streamlined procurement approaches

VIII. RISR MANAGEMENT

1. SYSTEMS APPROACH TO ENVIRONMENTAL MANAGEMENT

- Decision framework for comparing/minimizing risks

- Economic, political, technical, schedule, health, etc. tradeoffs

- Need acceptance (public, decision makers) of risk tradeoffs

- Concerns over worker/public exposure during cleanup

- Concerns over true risk reductions from cleanups

- Natural system controls

- Technology limitations

- $\quad$ Need broad based input

- Need tools

Support Activities:

A. Develop risk management approach to decision making

IX. FUIURE LAND USE

- Key to defining cleanup approaches/levels

- Policy integrated into PEIS

- National/regional/State natural resources

- Waste storage/disposal areas needed

- Institutional controls may exist

Support Activities:

A. Develop land use policy

X. CLEANUP LEVELS

1. LIMITED CLEANUP STANDARDS

- No soil cleanup standards

- Isotope-specific standards missing (soil, groundwater)

- Cleanup levels for D\&D facilities

- Tied to land use 
Support Activities :

A. Work with EPA and ATSDR

2. BASIS FOR CLEANUP LEVELS

- Technology driven

- Regulation driven

- Health/risk driven

- How to measure/judge cleanup success

Support Activities:
A. Clarify basis for cleanup levels
B. Assess attainability of cleanup levels
c. Asses risk-driven benefits

3. FLEXIBILITY OF REMEDIAL ACTION CLEANUPS

- Following prescribed cleanup levels--conservative approach

- De minimis contaminant levels

- Cleanups based on letter of law rather than on risk

Support Activities:

A. Promote risk-driven cleanups

4. COMMON TERMINOLOGY REQUIREMENTS

- Definitions: Pristine; Background; BDAT; Below Regulatory Concern

Support Activities:
A. Agree on common terminology with regulators
B. Factor into Agreements

XI . DOE INFRASTRUCTURE
- Staff
- Subcontractors
- TSD Facilities
- Laboratories
- Funding levels
- Master plan guiding strategic planning
- Decision aiding tools and data bases 
XII. INFORYATION SYSTEMS

- Access (internal and external) to data

- Traceable linkage from collection to use

- Electronic systems

- Preserve knowledge base

- Common linkage across DOE

- Motivation to share information required

- Characterization, technology, and treatability data

Support Activities:
A. Assess data/information generation
B. Define access/storage/retrieval needs
C. Develop guidance
D. Evaluate existing systems/capabilities

XIII. COMLONITY RELATIONS PROGRAY

- Organizational visibility
- Grogram reviews
Guidance

Support Activities:

A. Develop accountable organization

B. Issue guidance 
APPENDIX G

GENERAL WORKSHOP INFORMATION 


\section{APPENDIX G}

\section{GENERAL WORKSHOP INFORMATION}

The following items were part of the December workshop:

$\begin{array}{lc}\text { Workshop Agenda } & G .2 \\ \text { Workshop Product Roadmap } & G .4 \\ \text { Explanation of Small Group Process } & G .5 \\ \text { Attendees List } & G .6 \\ \text { Letter of Acknowledgment for Participation } & \\ \quad \text { from EM-40 } & G .10\end{array}$

G. 1 


\section{ER REGULATORY AND INSTITUTONAL ISSUES WORKSHOP AGENDA}

\section{Monday, December 17, 1990}

8:00 Registration

8:15 Convene and Introductions (Bill Fallon)

8:30 ER/EH Welcome and Opening Remarks (Pat Whitfield and Ray Berube)

Participant Questions or Feedback

9:00 Workshop Overview (Bill Fallon)

9:15 Presentation of Issues (Roy Gephart)

10:30 Break

10:45 Voting to Select Five issue Groups for Detailed Small Group Discussion (Roy Gephart)

11:45 Sign-up for Afternoon Small Group Sessions (Roy Gephart)

12:00 Lunch

1:00 Small Group Session (All)

Break

5:00 Closing Comments (Facilitators) 


\section{ER REGULATORY AND INSTITUTIONAL ISSUES WORKSHOP AGENDA}

Tuesday, December 18, 1990

8:00 Check In

8:15 Reconvene (Bill Fallon)

$$
\begin{aligned}
& \text { Recap } \\
& \text { Preview } \\
& \text { Business }
\end{aligned}
$$

8:30 Group Reports and Plenary Feedback (Roy Gephart)

10:45 Break

11:00 Remarks/Questions and Answers (Pat Whitfield)

11:30 Adjourn (Bill Fallon)

t1:45 Lunch 


\section{WORKSHOP PRODUCT ROADMAP}

ISSUE GROUP

ISSUE 1.

ISSUE 2 ISSUE (n)

HISTORY

- WHATS BEEN DONE

- WHO

- WHEN

- RESULTS

- PROBLEMS

- PRODUCT

SEQUENTIAL ACTION ITEMS

1.

2.

3.

4.

PROCEED TO ISSUE 2

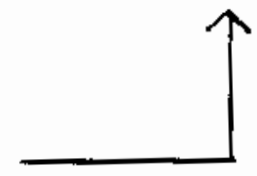

G.4 


\section{Explanation of Small Group Process}

1) Review the list of issues in the issue group you are working on. Accept, modify or add to the issues until group is satisfied. Careful not to coopt another group's issue.

2) Arrange the issues into the order in which the group wishes to work them. (This may be important tomorrow since reporting out time is limited.)

3) Select first issue.

4) Develop a history/elaboration of steps, activities, or products that have been taken or attempted to resolve the issue. E.g., try to capture: what has been undertaken, by whom, where and when. Was the effort successful, why or why not, are products available? Capture on storyboard.

5) Develop an action item sequence, i.e. a sequential list of steps or activities which, if successtully implemented, would resolve the issue. Capture on storyboard.

6) Pick next issue - go to step four.

7) If your group gets through alt the issues in your issue group and adequate time remains, select the runner-up issue group and continue process.

8) Close-out points at end of day 1

- Be on time tomorrow, Whittield's schedule is tight.

- Evening work is OK but workshop team is unavailable

- Next day activities:

- Group Leader presents results to large group and Mr. Whittield. Time will be limited to 20 minutes including audience feedback. Use either story boards or overheads. Groups should sit together.

- Facilitators will capture audience feed back. 
REGULATORY INSTITUTIONAL ISSUES WORKSHOP, DECEMBER 17-18, 1990

ATTENDEES

\author{
Marvis Aleem \\ U.S. Department of Energy \\ EM-20/FORS \\ JuTie D'Ambrosia \\ NJG, Inc. \\ Germantown, MD 20874 \\ John Andrews \\ U.S. Department of Energy \\ AT buquerque Operations Office \\ Albuquerque, NM 87115 \\ Jim Bauer \\ Westinghouse Hanford Company \\ Richland, WA 99352 \\ Raymond Berube \\ U.S. Department of Energy \\ EH-20/FORS \\ Susan Brechbill \\ U.S. Department of Energy \\ Office of Chief Counsel \\ Oakland, CA 94612 \\ David Brown \\ Allied Signal, Inc. \\ Kansas City, M0 64141-6159 \\ Thomas Buqo \\ Earth Technology Corporation \\ Las Vegas, NV 89109 \\ Joe Cullen \\ U.S. Department of Energy \\ San Francisco Operations Office \\ Oakland, CA 94612 \\ Richard Dailey \\ U.S. Department of Energy \\ EH-231/FORS \\ Paul Davis \\ Sandia National Laboratory \\ Albuquerque, NM 87185
}


George Dixon

U.S. Department of Energy

EM-20/FORS

Keener Earle

Westinghouse Idaho Nuclear Company, Inc.

Idaho Falls, ID 83403-4000

Robert Faron

U.S. Department of Energy

GC-11/FORS

Lisa Feldt

U.S. Department of Energy

EH-22/FORS

Donald Fulmer

U.S. Department of Energy

EM-42/GTN

Lisa Green

U.S. Department of Energy

Idaho National Engineering Laboratory

Idaho Falls, ID 83415

Raymond Greenberg

U.S. Department of Energy

EM-45/GTN

Lyle Harris

U.S. Department of Energy

EM-44/GTN

Joel Hebdon

EG\&G Idaho, Inc.

Idaho Falls, ID 83415-1401

Fred Hoffman

Lawrence Livermore National Laboratory

Livermore, CA 94550

Robert Holt

U.S. Department of Energy

Richland Operations Office

Richland, WA 99352

John Hoover

Argonne National Laboratory

Washington, DC 20024-2115 
Robert Howe

Brookhaven National Laboratory

Upton, NY 11973

Randa11 Kaltreider

U.S. Department of Energy

EH-22/FORS

Roger Landon

West inghouse Hanford Corporation

Richland, WA 99352

Fraser Lockhart

U.S. Department of Energy

Rocky Flats Area Office

Golden, CO 80402-0928

Sally Mann

U.S. Department of Energy EM-44/GTN

Stephen Mellington

U.S. Department of Energy

Nevada Operations Office

Las Vegas, NV 89193-8518

Jerome Miller

Martin Marietta Energy Systems

Oak Ridge, TN 37830

Carolyn Osborne

U.S. Department of Energy

EH-25/FORS

Autar Rampertaap

U.S. Department of Energy

EM-45/GTN

Walter Sato

U.S. Department of Energy

Idaho Operations office

Idaho Falls, ID 83402

Rich Sena

U.S. Department of Energy

Albuquerque Operations office

Albuquerque, NM 87115

Robert Sleeman

U.S. Department of Energy

Oak Ridge Operations

Oak Ridge, TN 37831 


\author{
Lars Soholt \\ LoS Al amos National Laboratory \\ Los Alamos, NM 87556 \\ David Swindle \\ Martin Marietta Energy Systems, Inc. \\ Oak Ridge, TN 37831-6248 \\ Lawnie Taylor \\ U.S. Department of Energy \\ EM-43/GTN \\ Thomas Traceski \\ U.S. Department of Energy \\ EH-231/FORS \\ Bill White \\ U.S. Department of Energy \\ Argonne Area Office \\ Argonne, IL 60439 \\ Pat Whitfield \\ U.S. Department of Energy \\ EM-40/FORS \\ Andre Willians \\ U.S. Department of Energy \\ EM-55/GTN \\ William Wisenbaker \\ U.S. Department of Energy \\ EM-42/GTN
}




\section{Department of Energy \\ Washington, DC 20585}

$19 \cdots \cdots \cdots: 3 ?$

Distribution

I would like to thank you again for your time and contributions to the Regulatory and Institutional Issues Workshop and the conference calis and meetings that preceded it. As I said at the workshop, the answers to the challenges we face will come primarily from the field. I was gratified by the interest, quality, and level of energy that was in evidence during the workshop. I am confident that the ideas you developed will facilitate the goal of issue resolution, and I reiterate my intention to implement them whenever possible.

At the close of the workshop, I expressed my personal belief that it is a privilege to serve on a program as important and significant as the Environment Restoration Program. Let me add that I am aware of the demands that the program places on each of you. Your dedication and commitment to the goal of environmental restoration are recognized and appreciated.

The workshop team is preparing a report which will be distributed through the field offices for comment and additional input this month. In commenting on the report, recall that the workshop was to mark the beginning of an ongoing process of issue identification, tracking, and resolution. Your comments on how to enhance, implement, or manage this process will be most valuable.

Thank you again for your participation.

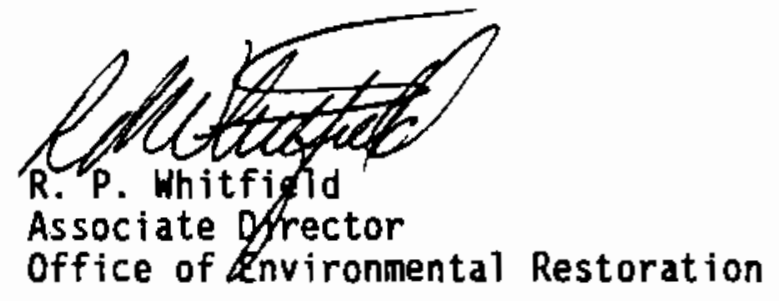




\section{APPENDIX $\mathrm{H}$}

POTENTIAL RESOURCES FOR ADDRESSING WORKSHOP ISSUE GROUPS 


\section{APPENDIX H}

\section{POTENTIAL RESOURCES FOR ADDRESSING WORKSHOP ISSUE GROUPS}

The following individuals were indicated as having an interest and/or expertise in working on the following issue groups.

REGULATORY STREAMLINING
Leah Deaver
EH-22
U.S. Department of Energy
1000 Independence Ave. S.W.
Washington, DC 20585
J.D. Ditmars
Argonne National Laboratory

FTS $972-5952$

Lisa Feldt

EH-22

U.S. Department of Energy 1000 Independence Ave. S.W. Washington, DC 20585

L. John Hoover

Argonne National Laboratory Washington, DC 20024-2115 (202) $488-2446$

Randy Kaltreider

EH-22

U.S. Department of Energy 1000 Independence Ave. S.W. Washington, DC 20585

Frank Russo

EH-22

GENERAL DOE GUIDANCE

Don Riley

EM, Rocky Flats

FTS 345-2244

\section{CLEANUP LEVELS}

David Brown

Allied-Signal, Kansas City Plant Kansas City, M0 64141-6159

(816) $997-4034$

\section{A. Dvorak Argonne National Laboratory (708) $972-3107$}

L. Hubegger

Argonne National Laboratory (708) $972-3791$

Phil Keary DOE-Kansas City Area Operations Kansas City Plant (816) 997-7288

James L. Littlejohn

DOE-Nevada ER Branch, ER and WM Division FAX FTS 575-1810

Lars Soholt

Los Alamos National Laboratory

Los A1 amos, NM 87556

FTS $843-2257$

EM INTEGRATION

Brookhaven National Laboratory ER and WO Groups

D.M. Eggers

Al lied Signal, Kansas City Plant (816) $997-4045$ 
Phil Keary

DOE-Kansas City Area Operations Kansas City Plant

(816) $997-7288$

Greg Moore

PRNP

Rocky Flats

FTS 345-3892

D.L. Stoltz

Allied Signal, Kansas City Plant (816) 997-4175
IMPLEMENTATION OF

AGREEMENTS/DOCUMENTATION

Paul Aamodt

Los Alamos National Laboratory ER

FTS 843-7960

FAX FTS 855-4747

Doris Garvey

Los Alamos National Laboratory

Env. Protection

FTS $855-2380$ 


\section{DISTRIBUTION}

No, of

Copies

QFFSIIE

12 DOE/Office of Scientific and Technical Information

M. Aleen

U.S. Department of Energy $\mathrm{EM}-20$

1000 Independence Avenue S.W. Washington, DC 20585

J. Andrews

U.S. Department of Energy

Albuquerque Operations Office Box 5400

Albuquerque, NM 87115

R. Berube

U.S. Department of Energy $\mathrm{EH}-20$

1000 Independence Avenue S.W. Washington, DC 20585

S. Brechbill

U.S. Department of Energy

San Francisco Operations Office

1333 Broadway

Oakland, CA 94612

J. Cullen

U.S. Department of Energy

Livermore Site Office

8000 East Ave.

Box 808-L-574

Livermore, CA 94550

R. Dailey

U.S. Department of Energy

$\mathrm{EH}-231$

1000 Independence Avenue S.W. Washington, DC 20585
No. of

Copies

G. Dixon

U.S. Department of Energy

$\mathrm{EM}-20$

1000 Independence Avenue S.W. Washington, DC 20585

R. S. Faron

U.S. Department of Energy

GC-11

1000 Independence Avenue S.W.

Washington, DC 20585

L. Feldt

U.S. Department of Energy

$\mathrm{EH}-22$

1000 Independence Avenue S.W.

Washington, DC 20585

J. Fiore

U.S. Department of Energy

Nevada Operations Office

Box 98518

Las Vegas, NV 89109

D. Fulmer

U.S. Department of Energy

EM-42

19901 Germantown Rd.

Germantown, MD 20545

L. Goidel1

U.S. Department of Energy

Savannah River Operations Office

Box A

Aiken, SC 29802

L. Green

U.S. Department of Energy

Environmenta1 Program Branch

785 DOE Place

Idaho Falls, ID 83415 
No. of

Copies

R. I. Greenberg

U.S. Department of Energy EM-45

19901 Germantown Rd.

Germantown, MD 20545

L. Harris

U.S. Department of Energy EM-44

19901 Germantown Rd.

Germantown, MD 20545

J. Haugen

U.S. Department of Energy Chicago Operations office 9800 South Cass Ave.

Chicago, IL 60439

R. KaTtreider

U.S. Department of Energy $\mathrm{EH}-22$

1000 Independence Avenue S.W.

Washington, DC 20585

F. Lockhart

U.S. Department of Energy

Rocky Flats Area Office

Box 928

Golden, C0 80402-0928

J. LyTe

U.S. Department of Energy Idaho Operations office 785 DOE P1ace

Idaho Falls ID 83402

S. Mann

U.S. Department of Energy EM-44

19901 Germantown Rd.

Germantown, MD 20545

L. McClain

U.S. Department of Energy

Savannah River Operations office

Box A

Aiken, SC 29802
No. of

Copies

S. Mellington

U.S. Department of Energy

Nevada Operations office

Box 98518

Las Vegas, NV 89109

C. Osborne

U.S. Department of Energy

$\mathrm{EH}-25$

1000 Independence Avenue S.W.

Washington, DC 20585

A. Rampertaap

U.S. Department of Energy

EM-45

19901 Germantown Rd.

Germantown, MD 20545

W. N. Sato

U.S. Department of Energy

785 DOE Place

Idaho Falls, ID 83402

R. Schassburger

U.S. Department of Energy

Rocky Flats office

Rocky Flats Plant

GoTden, C0 80402

R. Sena

U.S. Department of Energy

Albuquerque Operations Office

Box 5400

ATbuquerque, NM 87115

c. Sherman

U.S. Department of Energy

Savannah River Operations Office

Box A

Aiken, SC 29802 
PNL -7692

UC -902

No. of

Copies

R. Sleeman

U.S. Department of Energy

Oak Ridge Operations/EW91

200 Administration Rd.

0ak Ridge, TN 37831

D. Smith

U.S. Department of Energy

EM-431

19901 Germantown Rd.

Germantown, MD 20545

L. Taylor

U.S. Department of Energy

$\mathrm{EM}-43$

19901 Germantown Rd.

Germantown, MD 20545

T. Traceski

U.S. Department of Energy

EH-231

1000 Independence Avenue S.W.

Washington, DC 20585

G. Turi

U.S. Department of Energy

EM- 433

19901 Germantown Rd.

Germantown, MD 20545

B. White

U.S. Department of Energy

9800 S. Cass Avenue S.W.

Argonne, IL 60439

R. P. Whitfield

U.S. Department of Energy EM-40

1000 Independence Avenue S.W.

Washington, DC 20585

W. Wisenbaker

U.S. Department of Energy EM-43

1991 Germantown Rd.

Germantown, MD 20545
No. of

Copies

K. Earle

Westinghouse Idaho Nuclear

Company, Inc.

Box 4000

Idaho Falls, ID 83403-4000

J. Miller

Martin Marietta Energy Systems

Blair Highway 58, B]dg. 1330

Oak Ridge, TN 37830

P. Davis

Sandia National Laboratory

1515 Eubank N.E.

Box 5800, Org 3223

A1buquerque, NM 87123

J. Hebdon

EG\&G Idaho, Inc.

1955 Fremont Avenue

Idaho Falls, ID 83415-1401

F. Hoffman

Lawrence Livermore Nationa 1 Laboratory

8000 East Ave.

Box 808-L-528

Livermore, CA 94550

J. Hoover

Argonne National Laboratory

370 L'Enfant Promenade

Washington, DC 20024-2115

R. Howe

Brookhaven National Laboratory

53 Bell Ave

Upton, NY 11973

J. D'Ambrosia

NJG, Inc.

13204 Executive Park Terrace

Germantown, MD 20874 
No. of

Copies

D. Brown

Allied Signal, Inc.

Dept. 922/SC-8

Box 419159

Kansas City, MO 64141-6159

T. Buqo

Earth Technology Corp.

1700 E. Desert Ave.

Las Vegas, NV 89109

A. Williams

U.S. Department of Energy

EM-55

19901 Germantown Rd.

Germantown, MD 20545

L. Sohott

Los Alamos National Laboratory

Bikini Rd. SM30

K481

Los Alamos, NM 875545

D. Swindle

Martin Marietta Energy

Systems, Inc.

Oak Ridge 25 Site

Blair Rd., Highway 58

B1dg K1330, MS 7298

Oak Ridge, TN 37831-7298

\section{ONSITE}

DOE Richland Operations office

J. Bauer

U.S. Department of Energy

Richland Operations office

Box 550

Richland, WA 99352

R. Carosino

U.S. Department of Energy

Richland Operations office

Box 550

Richland, WA 99352
No. of

Copies

R. Freeberg

U.S. Department of Energy

Richland 0perations office

Box 550

Richland, WA 99352

R. Holt

U.S. Department of Energy

Richland Operations office

A/5-19

Box 550

Richland, WA 99352

West inghouse Hanford Company

R. Landon

Westinghouse Hanford Company

Box 1970/B2-19

Richland, WA 99352

92 Pacific Northwest Laboratory

R. C. Adams

G. R. Bilyard

W. E. Fallon (BWO) (75)

C. A. Geffen (BWO)

J. M. Gephart

R. E. Gephart

J. F. Keller

T. L. Kuusinen

J. D. Longstreth $\left(B W_{0}\right)$

R. V. Moraski (BWO)

L. A. Stevenson (BWO)

R. D. Quinn (BWO)

Publishing Coordination

Technical Report Files (5) 